


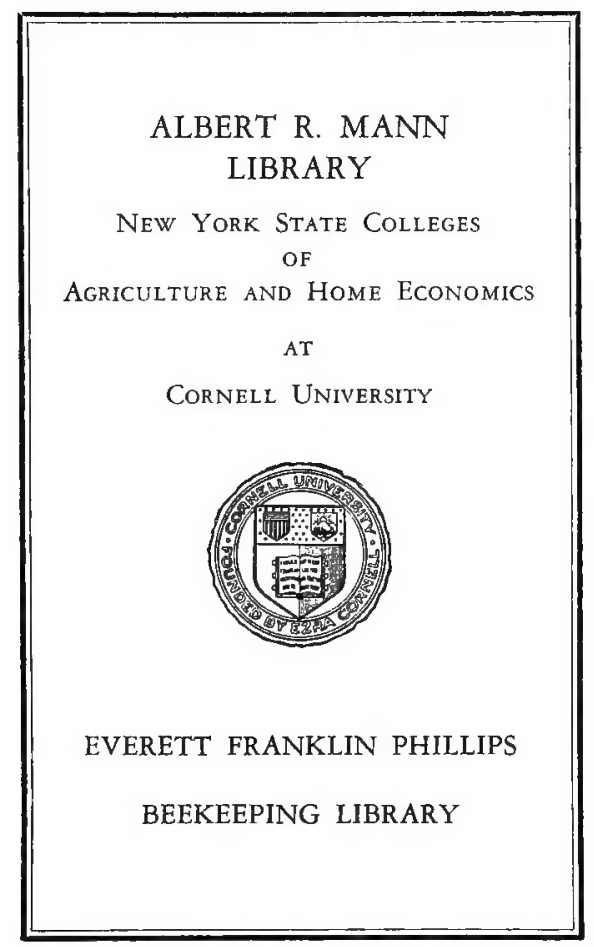


State of Rhlyode $\mathbb{I s l a n d}$ and providence plantations.

\section{S'TA'TE BOARD OF AGRICULTURE. \\ JoHN J. DUNN, secretary. \\ ENTOMOLOGICAL DEPARTMENT.}

A. EDWARD STENE, Entomologist.

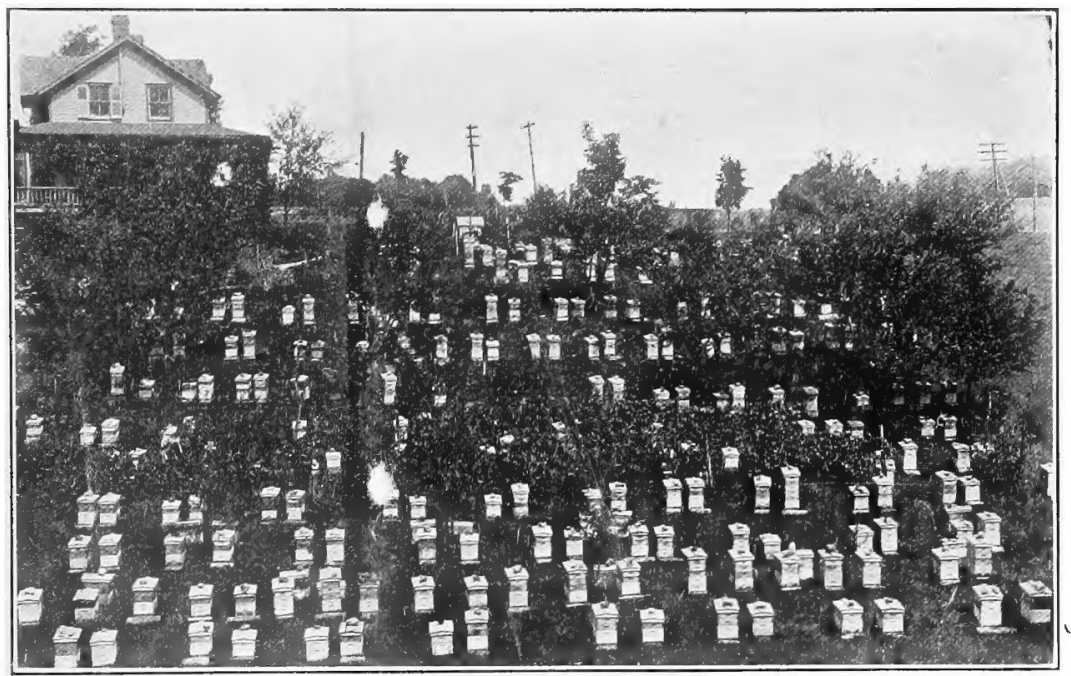

Not a Rhode Island Apiary but one worthy of consideration by Rhode Island Bee keepers.

\section{BEE KEEPING IN RHODE ISLAND. \\ ARTHUR C. MILLER.}

Abstract from Report of State Board of Agriculture for 1910.

\section{PROVIDENCE :}

E. L. FRELMAN COMPANY, STATE PRINTERS. 


\section{Cornell University Library}

The original of this book is in the Cornell University Library.

There are no known copyright restrictions in the United States on the use of the text.

http://www.archive.org/details/cu31924003243346 


\title{
BEE KEEPING IN RHODE ISLAND.
}

\author{
Arthur C. Miller.
}

\section{IS RHODE ISLAND ADAPTED TO BEE KEEPING?}

Bee keeping as a profitable pursuit in connection with some other business, or as an exclusive vocation is just beginning to assume its proper place in the industries of the State.

Investigations of the honey-producing possibilities of Rhode Island have shown that in yield per colony and quality of the honey it ranks well with other northern states. Many parts of the State are particularly good for bee keeping, and only those parts most fully covered with woods and brush are unfavorable.

\section{The Principal Sources of Honey Are:}

First.-Blossoms of the fruit-bearing trees and shrubs, such as apple, cherry, pear, blueberries, raspberries, etc., together giving a light colored honey of fine flavor and body.

Second:- White and alsike clover, and in some sections locust. Honey from these sources is of the highest grade.

Third:-The sumachs, clethra, clematis, the European linden, where found, and occasionally, in some places, clover. All of these sources yield honey of good quality, although that from clethra is rather too spiey to please all palates.

Fourth:- The goldenrods and asters, which yield a fine aromatic honey.

Cost of Equipment. Labor Required.

The investment per colony need not exceed ten dollars for the first one or two, and thereafter only the hives need be bought. The 
average yield per colony under fair management is fifty pounds, while individual colony yields have gone above three hundred pounds. The wholesale prices range from ten cents to eighteen cents per pound, varying with quality and package, and the retail prices are from fifteen cents to thirty cents.

Modern methods of management have over'ome many of the seeming annoyances of the past, and the labor involved is slight as compared with what is necessary for any other live stock.

The Market's Demand for Honey.

The Rhode Island market for honey is very good but it is at present supplied largely from without the State. Climatic conditions are favorable for bee culture, and there seems to be no good reason why it should not be undertaken by many more persons than are now engaged in it. A few persons are already extending their apiaries, looking forward to bee keeping as an exclusive business.

\section{Bee Keeping and Orcharding.}

The orchardists are beginning to realize the importance of having bees in or near their orchards, and are either buying bees or offering inducements to bee keepers to move bees to their vicinity.

\section{Difficulties in Bee Kieiping.}

Some bee keepers are not getting the returns they might from their bees, and the greenhouse and fruit men often find the keeping up of the necessary stock of bees no small expense. These results are due chiefly to incomplete knowledge as to the proper care of bees and partly to losses caused by diseases.

\section{Control of Bee Diseases.}

At the present time there seems to be no contagious diseases of bees within the State, though such exist close to the northern and western border. Reasonable care should hinder their introduction and prompt action prevent their spread, should they obtain a foot- 
hold. Under the existing law, copied in full below, for the control of bee diseases, an inspector is appointed to aid bee keepers in the eradication of the diseases if found among their bees or bees in their vicinity, and to give such suggestions as he may deem advisable.

An Act Providing for the Inspection of Apiaries and the Suppression of Contagious Diseases Among Bees.

It is enacted by the General Assembly as follows:

Section 1. The state board of agriculture is hereby authorized to appoint some qualified person to be state inspector of apiaries, and he is empowered to appoint one or more assistants as needed, who shall carry on the work under his supervision.

SEC. 2. The inspector or his assistant shall at his option or when notified in writing by the owner of an apiary, or by any three disinterested taxpayers, examine all reported apiaries, and all others in the same locality not reported, and ascertain whether or not the diseases known as American foul brood or European foul brood, or any other disease which is infectious or contagious in its nature, and injurious to honey bees in their egg, larval, pupal, or adult stage, exists in such apiaries; and if satisfied of the existence of any such diseases he shall give the owners or care-takers of the diseased apiaries full instructions how to treat such cases, as, in the inspector's judgment, seem best.

SEc. 3. The inspector or his assistant shall visit all diseased apiaries a second time, after ten days, and, if need be, burn all colonies of bees that he may find not cured of such disease, and all honey and appliances which would spread disease, without recompense to the owner, lessee, or agent thereof.

SEC. 4. If the owner of an apiary, honey, or appliances, wherein disease exists, shall sell, barter, or give away, or move without the consent of the inspector any diseased bees (be they queens or workers) colonies, honey, or appliances, or expose other bees to the danger of such disease, or fail to notify the inspector of the existence of such 
disease, said owner shall, on conviction, be liable to a fine of not less than ten dollars nor more than one hundred dollars.

SEc. 5. For the enforcement of the provisions of this act, the state inspector of apiaries or his duly authorized assistants shall have access, ingress, or egress to all apiaries or places where bees are kept; and any person or persons who shall resist, impede, or hinder in any way the inspector of apiaries in the discharge of his duties under the provisions of this act shall on conviction be fined not less than ten nor more than one hundred dollars for each offence.

SEC. 6. After inspecting infected hives or fixtures or handling diseased bees, the inspector or his assistant shall, before leaving the premises or proceeding to any other apiary, thoroughly disinfect any portion of his person and clothing and any tools or appliances used by him which have come in contact with infected material, and shall see that any assistant or assistants with him have likewise thoroughly disinfected their persons and clothing and any tools and implements used by them.

SEc. 7. It shall be the duty of any person in the State of Rhode Island engaged in the rearing of queen-bees for sale, to use honey in the making of candy for use in mailing-cages, which has been boiled for at least thirty minutes. Any such person engaged in the rearing of queen-bees shall have his queen-rearing apiary or apiaries inspected at least twice during each summer season; and on the discovery of the existence of any disease which is infectious or contagious in its nature, and injurious to bees in their egg, larval, pupal, or adult stage, said person shall at once cease to ship queen-bees from such diseased apiary until the inspector of apiaries shall declare the said apiary free from all disease. On complaint of the inspector of apiaries, or of any five bee keepers in the state, that said bee keeper engaged in the rearing of queens is violating the provisions of this section, he shall, on conviction, be liable to a fine of not less than twenty-five nor more than one hundred and fifty dollars.

SEC. 8. The inspector of apiaries shall make annual reports to the state board of agriculture giving the number of apiaries visited, the 
number of diseased apiaries found, the number of colonies treated, also the number of colonies destroyed, and the expense incurred in the performance of his duty. He shall also keep a careful record of the localities where disease exists; but this record shall not be public, but can be consulted with the consent of the inspector of apiaries.

SEc. 9. All fines collected under the provisions of this act shall be paid to the state treasurer, and by him added to the appropriation of the state board of agriculture, to he used in carrying out the provisions of this act.

SEC. 10. All acts or parts of acts inconsistent herewith are hereby repealed, and this act shall take effect June first, A. D. 1910.

\section{Bee Diseanes.}

There are two contagious diseases of bees now recognized, both of which attack the brood or bees in the larval stage, and are known respectively as American Foul brood and European Foul brood, the latter being sometimes called Black brood. The so-called Pickled brood is seldom met with and does not seem to be infectious. The term foul as applied to brood disease was given on account of the odor emanating from the dead brood.

The following is a description of the diseases mentioned and the general manner of their treatment.

\section{American Foul Brood.}

The cause of this disease is now known to be a microscopic organism called Bacillus larre, White. Dr. E. F. Phillips, in charge of. apicultural investigations of the U. S. Department of Agriculture describes this disease as follows:

*"When the larvæ are first affected they turn to a light chocolate color and in the advanced stages of decay become darker, resembling roasted coffee in color. Usually the larvæ are attacked at about

\footnotetext{
* The Brood Diseases of Bees. By E. F. Phillips, Ph. D. Circular 79, Bureau of Entomology, U. S. Department of Agriculture, pp. 1-2, 1906.
} 
the time of capping, and most of the cells containing infected larvæ are capped. As decay proceeds, these cappings become sunken and perforated, and, as the healthy brood emerges, the comb shows the scattered cells containing larvæ which have died of disease, still capped. The most noticeable characteristic of this infection is the fact that when a small stick is inserted in a larva which has died of the disease, and then slowly removed, the broken-down tissues adhere to it and will often stretch out for several inches before breaking. When the larva dries, it forms a dark brown color, which can best be observed when the comb is held so that a bright light strikes the lower side wall of the cell. Decaying larvæ which have died of this disease have a very characteristic: odor, which resembles a poor quality of glue. The disease seldom attacks drone or queen larva."

\section{European Fout Brood.}

1)r. Phillips describes this disease as follows:-

"This disease attacks larvæ earlier than does American foul brood, and a comparatively small percentage of the discased brood is ever "apped. The diseased larvæ which are capped over have sunken and perforated cappings. The larvæ when first attacked show a small yellow spot on the body near the head and move uneasily in the cell. When death occurs they turn yellow, then brown, and finally almost black. Decaying larvæ which have died of this disease do not usually stretch out in a long thread. when a small stick is inserted and slowly removed. Occasionally there is a very slight "ropiness," but this is never very marked. The thoroughly dried larvæ form irregular scales, which are not strongly adherent to the lower side wall of the cell. There is very little odor from decaying larvæ which have died from this disease, and when an odor is noticeable it is not the "glue-pot" odor of the American foul brood, but more nearly resembles that of soured dead brood. This disease attacks drone and queen larvæ very soon after the colony is infected. It is as a rule much more infectious than American foul brood and spreads more rapidly. On the other hand, it sometimes happens 
that the disease will disappear of its own accord, a thing which the author never knew to occur in a genuine case of American foul brood. European foul brood is most destructive during the spring and early summer, often almost disappearing in late summer and autumn."

If taken in time, both of these diseases may be controlled without serious loss to the bee-keeper, but if allowed to go unchecked, they will soon ruin any apiary, great or small.

The basis of treatment of both diseases is to deprive the infected colonies of all combs, whether empty or containing brood or honey, the bees being put into a new or thoroughly disinfected hive and allowed to start housekeeping anew. It will be from four to six days before they have any young to feed, and by that time all the honey they had in their honey sacs when taken from their infected hive will be gone, and the young will receive pure food, fresh from the flowers.

Except in fairly large apiaries, it is not worth while trying to save any of the brood from infected colonies. When it is desired to save such brood, it should all be given to one or two diseased colonies and allowed to remain for two or three weeks, after which these colonies should also be treated. In transferring diseased brood it is best to put it above a queen-excluding honeyboard, so that the queen of the colony may not lay eggs in the diseased combs. It is not wise to dequeen such colonies, for colonies without a queen are less likely to keep out robbers, and if robbers gain access to the infected honey, the disease will then appear in the colonies to which they belong. The combs from diseased colonies may be melted and the wax recovered, and wax from such sources appears to be safe to use in foundation making, etc. The refuse from the combs should be burned. The honey as a rule is not worth trying to save. It is so difficult to sterilize it, that its return to the bees for food is most unwise. If it is clear and nice, its use as human food is all right, for the microscopic plants are harmless to the human system. But do not let a single drop of it get to the bees.

The frames from diseased colonies may be saved by immersing them for a few minutes in a very strong solution of washing soda 
that is kept boiling during the operation. As soon as all wax and bee glue (propolis) are dissolved from the frames, they are rinsed in clear water, and after drying are ready for use again. Hive bodies, floors, covers, and other parts may be similarly treated, but usually it is easier to scorch these over with a gasoline torch, or by some similar' method.

\section{Pickled Brood.}

The larvæ die just preceding or just after capping and usually present a watery appearance. The cause is not known and the disease does not seem to be infectious.

It is usually treated by requeening, on the assumption that it is congenital.

\section{Diseases of Adult Bees.}

Paralysis is a disease of the adult bee. Its cause is not known and it is not common in the northern states.

Diarrhoea, or dysentery, as it is often called, is more properly a temporary digestive disturbance than a disease. It most frequently follows confinement to the hives for an undue length of time and under unfavorable conditions. Bees maintain the heat necessary for life by the consumption of honey. When the honey is deficient or low in the natural sugars, as when it is thin and unripe, or contains honey dew or an excess of pollen, they have to consume an undue amount to keep up the normal heat, and the system becomes over-loaded with waste matter. Unless the weather permits the bees to fly occasionally, the matter is voided in the hive and the trouble is aggravated.

Leaky or insufficiently ventilated hives will cause the bees extra effort to keep warm and so bring about the troulsle, even though the honey is perfect for their purpose. A warm, sunny day will usually cure the trouble, but if combs are badly soiled, it may be necessary to give the bees a clean set of combs and a clean hive and feed them some warm sugar-sirup. 
Moderate spotting of hives when bees fly in winter and spring need cause no alarm, but if the trouble seems excessive about any particular hive, it had better be opened and examined.

In case of trouble or suspected disease, bee-keepers are requested to write to the Entomological Department, State Board of Agriculture, State House, Providence, R. I.

The Entomological Department of the State Board of Agriculture has in preparation a bulletin on Modern Bee Culture written especially for Rhode Island conditions by the author of this article, and fully illustrated. When published it will be sent to all who will apply to John J. Dunn, Secretary of the Board of Agriculture, State House, Providence, R. I. 



\section{HOW TO KEEP BEES}

ARTHUR C. MILLER 



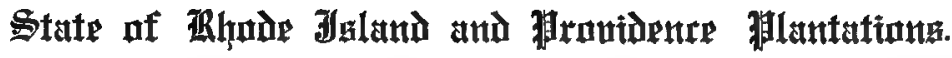

\section{STATE BOARD OF AGRICULTURE.}

JOHN J. DUNN, Secretary.

\section{Entomological Department.}

A. EDWARD STENE, Entomologist.

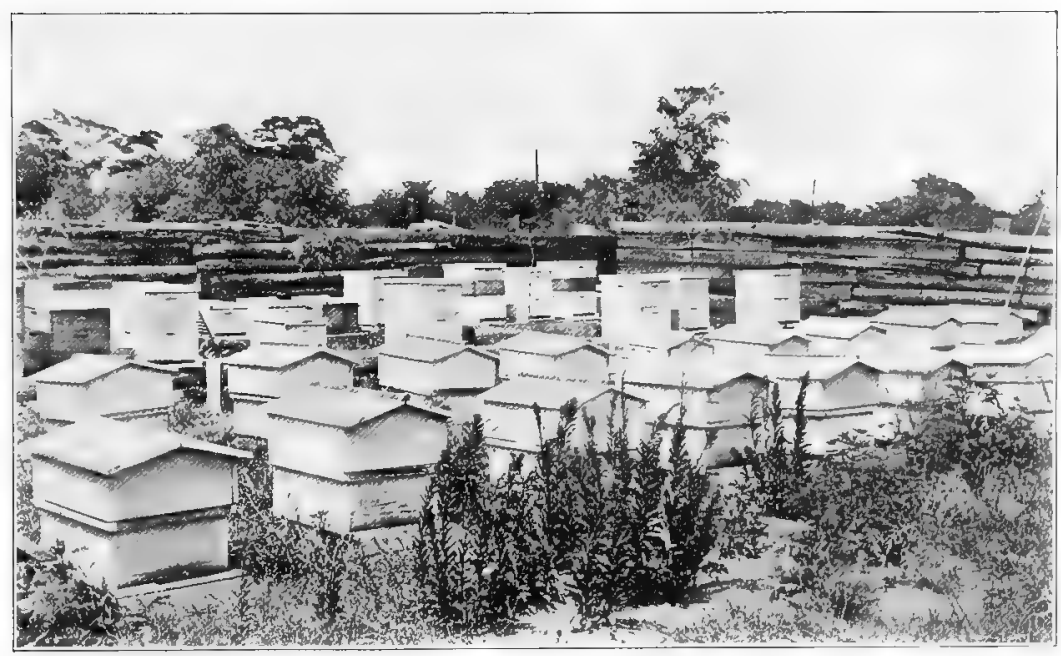

Part of a Fifty Colony Apiary at Howard, R. I.-After Providence Journal.

\section{HOW TO KEEP BEES. \\ ARTHUR C. MILLER.}

Abstract from Report of State Board of Agriculture for 1910.

PROVIDENCE:

E. I. FREEMAN COMPANY, STATE PRINTERS

1911, 


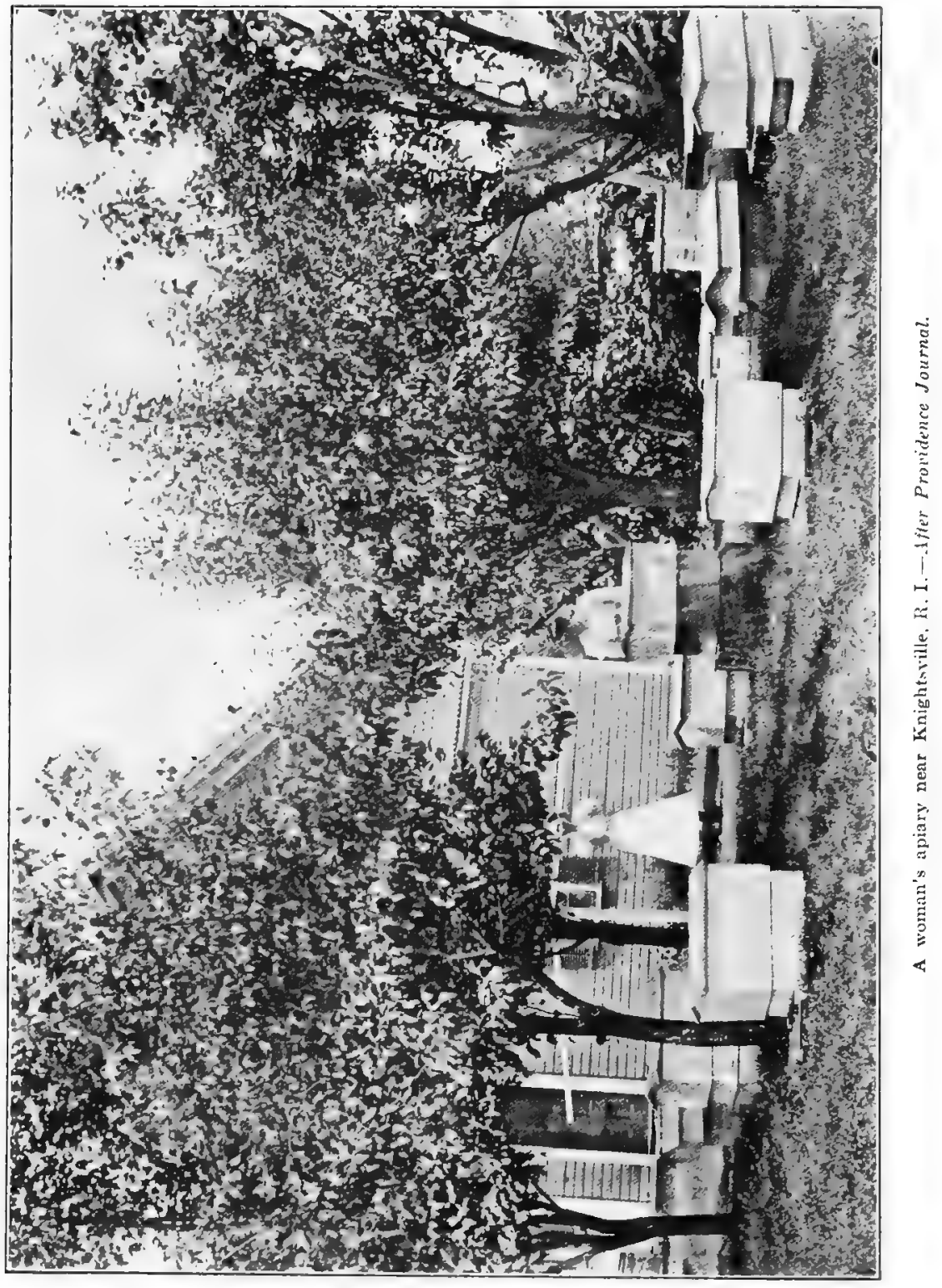




\section{PREFACE.}

Bee keeping as a pastime or hobby is quite extensively practiced in this as well as in other States. Only occasionally, however, do we find persons who enter into it as their principal business, or even as a money-making side line.

There is a good chance for an enlargement of this industry in Rhode Island. The market for good honey is not overstocked. In fact, we could with great advantage to ourselves supplant with honey some of the sweets now consumed, and it is safe to say that were the advantages of honey as a food well and generally known, and were the supply adequate, the number of bee keepers of both kinds, vocational as well as avocational, could be increased many times over without creating a surplus in the market.

From an economic standpoint also bee keeping should be encouraged. Bees gather and store for human consumption a product which is otherwise wholly wasted, and while so doing they render valuable service to the plants by aiding cross fertilization in return for the nectar secured. In the case of fruit trees, this is of immense advantage to the orchardist.

Bees require but little attention, and the outfit necessary for their care and housing is nominal in cost. While, as Mr. Miller states, our thickly forested areas are not adapted to extensive bee keeping, still there is abundant pasturage for a great many times the number of hives which are now in the State. It is therefore to be hoped that we may have in the near future a considerable increase in this industry, and it is the purpose of the Board of Agriculture to foster it so far as lies within its power. 
An excellent apiary inspection law has been passed which will aid in checking the spread of bee diseases and in the dissemination of better knowledge in regard to diseases and methods of eradicating them.

A brief bulletin entitled "Bee Keeping in Rhode Island," which deals with the principal bee diseases and their control, has already been issued. The present bulletin on "How to Keep Bees," aims to give a full account of the practice of bee keeping, and the fact that the author is a bee keeper of long experience, who not only knows the practical side, but has also sought the fullest information through other avenues, assures us that the directions presented can be given the fullest credence and can be studied to advantage by every bee keeper, but particularly by beginners who wish a brief and concise treatise relating to the industry.

The Board of Agriculture is indebted to the A. I. Root Company, Medina, Ohio, for all the cuts used in this bulletin, and to A. H. Gurney, of the Providence Journal, for the pictures from which halftones were made, showing apiaries at Howard and Knightsville.

A. E. Stene. 


\title{
HOW TO KEEP BEES.
}

\author{
Arthur C. Miller, \\ INSPECTOR OF APIARIES.
}

\section{INTRODUCTION.}

Rhode Island offers excellent opportunities for profitable bee culture. The soil is diversified, the flora is varied and extensive and the climate is not rigorous. Some of the more densely wooded parts of the State are not adapted to the pursuit as a business, nor even adapted to the support of more than a few colonies here and there. Other parts, particularly those having considerable dairy farming or fruit growing, are well adapted to bee culture on a substantial scale and here and there are locations which compare favorably with the best in the land and will profitably support large apiaries.

In times past bees were to be found on many farms and in many a village yard, but to-day they are far less often met with. The reasons for this condition are many, but probably the most important has been loss or meagre profit due to the lack of information as to the proper care of bees.

To aid in extending bee-keeping in this State and to make it easier and more profitable are the objects of this bulletin.

\section{PASTURAge.}

Bees may be kept almost anywhere and in almost any sort of a receptacle, but to make them profitable several factors must be considered. The first and most important is the pasturage, for if that is not good, all the skill in the world will avail but little. 
The sources of honey in Rhode Island grouped in the order of their appearance are willows, maples, elms and other less numerous trees which furnish the bees with the early supply of pollen and honey so useful and so needful in building up the bee population preparatory to the harvest in which the beekeeper shares.

Next comes the fruit blossoms, peach, plum, cherry, pear, apple, huckleberries and blueberries which, when the spring is favorable, yield good crops of the finest honey. In some places dandelions are an important addition to the fruit bloom, though not always coming at the same time. After the lapse of a week or ten days the main crop of the year comes from the white and alsike clovers. In some parts of the State these are accompanied by a heavy but brief flow of water-white honey from the locust, and are soon followed by ('hestnut which yields a rich, heavy, but dark honey.

In many sections sumacs furnish the next crop, and where they are abundant the beekeeper may rightly look for a good crop of a very fair honey.

In some of the more swampy and less settled sections, button bush, clethra (sweet pepper bush) and clematis yield a white and highly flavored honey, that from clematis being of the very highest quality. But the yield from these plants seems to be irregular, in some years being almost absent.

In some of the villages and cities the European Lindens are numerous and yield heavily. The bloom comes toward the end of the clover flow, though the time of flowering of different trees in the same neighborhood varies greatly. Native Linden (Basswood) is now found only in a few places. The season closes with the goldenrods and asters which yield a rich aromatic honey, but which is not acceptable to many persons. The crop from these two sources is not always to be clepended upon, being more affected by the weather than some of the others.

Many other flowers contribute to the harvest, but seldom to any great extent.

It is important that the bee-keeper should know well the pasturage 
of his bees and govern himself accordingly. If his crop must depend only on one of the groups, he must needs bend every energy to get that, but if he has two or more to depend on he can vary his plans.

Bees range for food about two miles from home, but the best results are secured when the pasturage is within a mile of the apiary. Bear these facts in mind when seeking the location for an apiary and if already located, make a careful inspection of the country round about and determine the sources of supply.

\section{LOCATION OF THE HIVES.}

The hives should be in a somewhat sheltered place, preferably where they get the morning sun and are shaded in the heat of the day. As the prevailing winds in the State are from the west and southwest, it has been found advantageous to face the hives to the southeast or cast. If on flat lands or low lands, by all means raise the hives about a foot from the ground. It puts them above a strata of cold fog which in the night often lies about six or eight inches deep in such places.

Having the hives so raised will be found to be helpful in other ways. They are more convenient to work at, are up out of the grass, weeds and dirt, and where sundry vermin will not disturh them.

Any convenient thing will do to set the hives on, but a stand made of spruce fence-rails after the following design has proved satisfactory in many years of service. The writer prefers a stand which will hold two hives and allow about eight inches between them. (See Figure 1.)

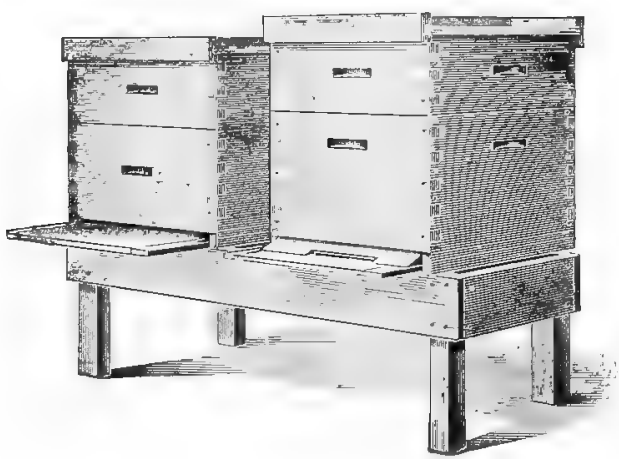

FIG. 1,-Hive Stand. 
If the legs are creosoted or limed, or lime or waste from electric batteries is put on the ground where they stand, they last a long time. Battery waste will also kill the grass and weeds.

\section{HIVES.}

Any of the hives commonly offered by the manufacturers of beekeepers supplies will do, but the more simple they are and the fewer the loose parts, the more satisfactory they will prove in the long run. Perhaps the most universal hive now in use is called the "Dovetailed" hive, named from the manner of its locked corners. (See Figure 2.) The hives known by this name all take the Langstroth frame, which measures $17 \frac{5}{8}$ by $9 \frac{1}{8}$ inches outside measure.

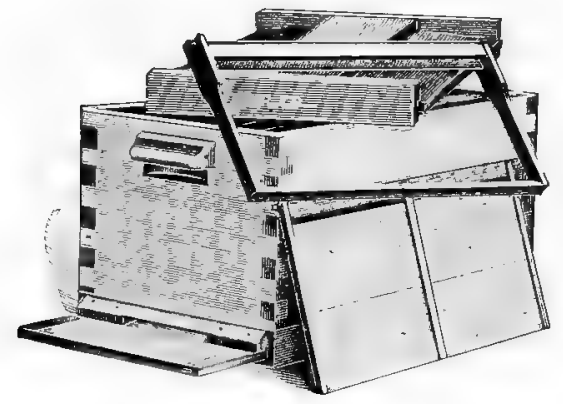

FIG. 2,-Dovetailed Hive.

These hives are commonly furnished in two widths called the eight-frame and the ten-frame. The former has had a great vogue but is now rapidly being discarded for the ten-frame size, and the beginner should be sure to get the latter. The keeper of a few colonies who contemplates increasing should by all means change to the larger size.

The hives having double walls with confined air spaces between or filled with chaff or sawrlust are good, but they cost more, are unwieldy, and in many ways lisis desirable. They are supposed to keep the bees warm in winter and make safer wintering, but as the temperature within the hive and outside of the cluster of bees in winter is practically the same as out of doors, the advantage is im- 
aginary rather than real. During the rest of the year, however, such hives are some help to the bees, but in this climate the advantages are not commensurate with the cost and inconvenience. An outer case answers the same purpose and is more convenient. (See Figure 3).

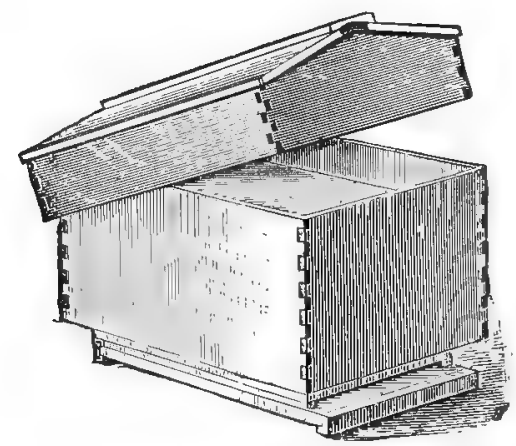

Fig. 3.-Outer Case.

Hives of different sizes and proportions are used and advocated by different persons. They are designed to meet some need of the beekeeper, or are based on some theory of bee habits, but with one exception it is believed they all call for a lot of attention and manipulation at critical times. The average person will do well to avoid them. There is one type of hive, however, which is designed to minimize labor and give average results. It is known as the "Let Alone" hive. The type was originally exploited by Gen. D. L. Adair, in the late ' 60 's, and was then called the "Long Idea" hive. Some few years ago Mr. Allen Latham of Norwich, Conn., experimented with it, and finally developed the present type which he has called the "Let Alone." It is approximately thirty-six inches long, twenty inches wide, and eighteen inches high. In the Adair hive the entrance was in the middle of the long side, in the Latham hive it extends across one end. Mr. Latham harl the advantage of an invention which Adair had not, namely, the so-called queen-excluding metal. Also Mr. Latham is a very careful student of bee habits, 
and with the knowledge acquired in many years' work with the bees, was able to accomplish what harl not before been done.

In the Aclair hive the queen harl the run of all the combs (about twenty); in the Latham hive she is confined to the seven at the front, being kept from the other's by a sheet of the queen-excluding metal. (See Figure t).

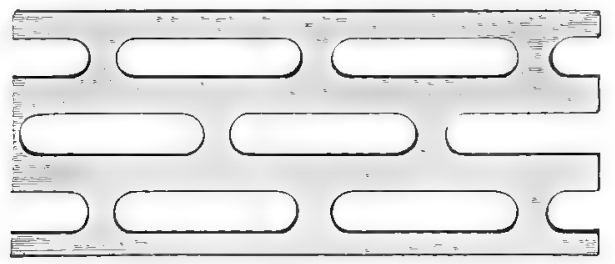

Fig. 4.-Excluder Metal.

These hives are really the tools of a high class specialist and while they will often succeed in the hands of a novice, their continued and uniform success on the minimum of labor plan calls for the knowledge only to be gained by long and careful observation of bees and their ways.

These are special hives which must be made to order. The frames are nourly five inches deceper than the standard Langstroth frame and these frames alio have to be made to order. The top bars and end bars of the frames touch the whole length when the frames are in place in the hive, so that the bers can only pass out at the bottom. Beveled cleats are nailed along the lower insicle corners of the hive and against these the bottom corn' '1's of the frames touch, keeping the bees from going behind the frames and virtually making a box within a box. The tops of the frames are about an inch below the top edge of the hive and Mr. Latham usis a few layers of newspapers and a thin wooden cover on top of the frames. The cover proper has a three inch rim and fits domm over the hive. Hive body and cover are covered with heary waterproof paper, black in color. The entrance which is an inch high, is guarded by a row of fine wire nails driven up through the floor. These are spaced far enough apart to permit the bees to pains freely and yet prevent the ingress of mice. 
The bees and qucen are started in the frames in the front end of the hive and are thereafter never disturbed unless external appearances indicate something wrong inside. When the bees have the front or brood compartment filled they spread through the excluder metal into the space behind. The frames there have only "starters" of comb foundation as guides for the becs. It the convenience of the beekecper the honey in these frames is removed and the frames returned.

\section{FRAMES, SUPERS, ETC.}

Frames may be placed in two classes, free hanging and self spacing, and the latter again into hanging and standing. Probably the most extensively used and the best for the beginner are the self spacing frames of the Hoffman type illustrated here. (Figure 5a).

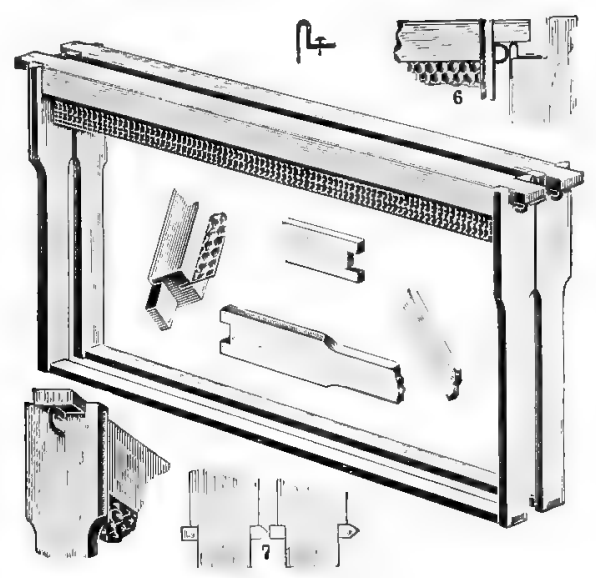

Fig. 5a.-Self-Spacing Frames.

These frames have grooves in the top bar for fixing the comb foundation and holes in the end bars for wires. Fine tinned wire is threaded through these holes, stretched tight and fastened. To these the sheets of foundation are fastened by embedding the wire in the wax. Various devices are sold for the purpose, but any narrow piece of iron with a notch filed in the end will do. The tail 


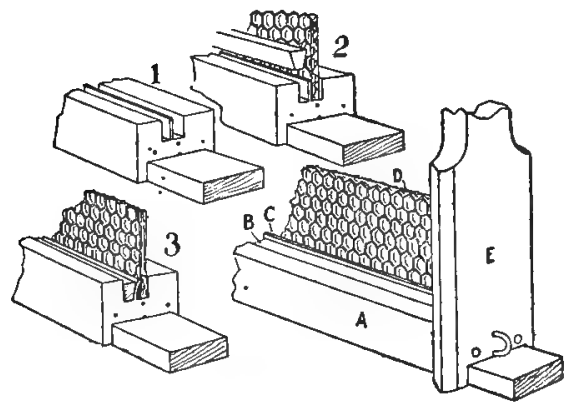

Fro. 5b.-Showing manner of fastening Foundation in Frame.

of an old file is just light. This is kept warm over an oil stove or lamp and is used hy drawing the notch along the wire, bearing on just enough to bed the wire without cutting through the shect of wax. In doing this work the frame is slipped over a board on which the foundation is iaid.

It is advisable to wire all brood frames as they may then be handled more readily, and if colonies of bees are shipped any distance, there will be no danger of wired combs breaking down.

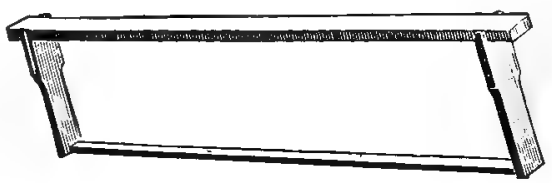

Fig. 6a.-Shallow Extracting Frime.

"Shallow frames" are much like the others except that they are only from 4y to is inches dere. They are used in shallow chambers

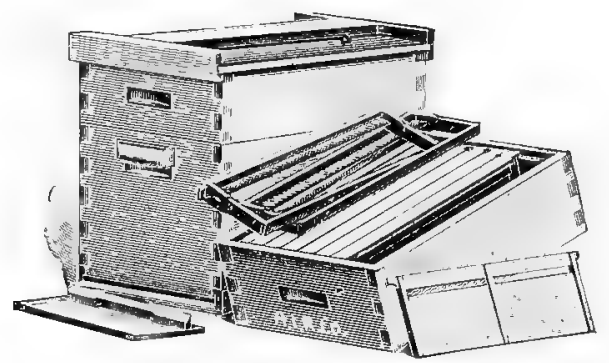

FIG. 6b.-Itive with Shallow Fxtracting Super. 
called supers, and the filled combs are either cut from them or uncapped, and the honey extracted. They are not usually wired. (Figures 6a and 6b).

Arrangements for producing honey in sections are somewhat more complicated. The shallow chamber is much the same as above, but special holders are provided for carrying small boxes or "sections" in which the bees build the combs. Strips of tin or wood separate each row of sections to prevent the bces bulging the surface of the combs. (Figure 7 ).

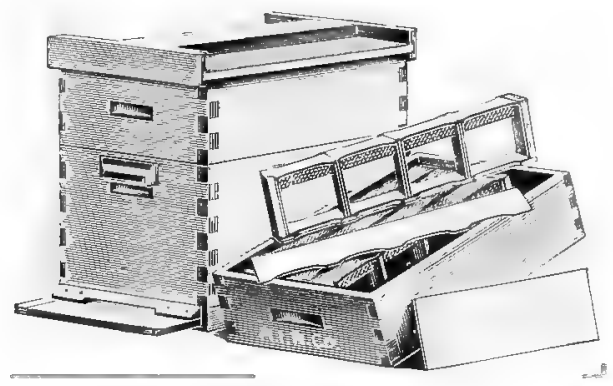

FIG. 7.-Hive with Comb Honey Super.

\section{HONEY BOARDS.}

Honey boards, so-called, are devices for use between the body (brood chamber) of the hive and the surplus compartment (super). The most satisfactory one is made of slats between which are fixed perforated strips of metal or accurately spaced wires to prevent the

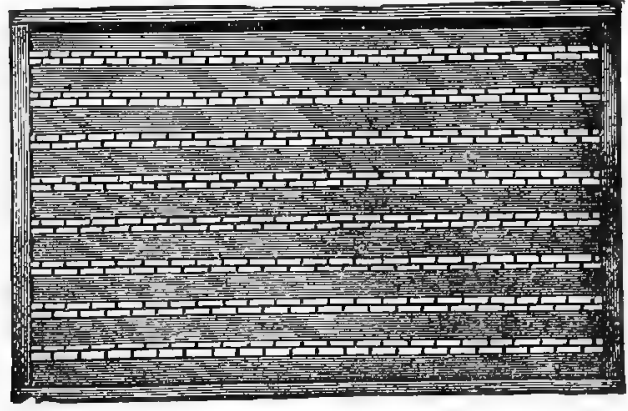

FIG. 8.-Honey Board. 
queen passing into the super. There is a rim around the edge so placed as to be flush on one surface and raised on the other, giving a bee space. The bee space sicle is used uppermost. (Figure S).

\section{BEE ESCAPES.}

A bee escape is a sort of fly trap clevice, permitting the passage of the bees in one direction only, and is used in a board placed between the brood chamber and the super to free the super from bees when

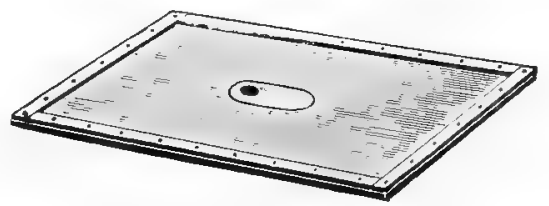

FIG. 9.-Bee Escape in Board.

it is clesired to remove the honey. It is a most useful contrivance, but its success depends upon there being no brood in the supers. (Figure 9).

\section{DRONE AND QUEEN TRAP.}

The drone and queen trap is a fro compartment box for use at the hive entrance to cat ch clrones and the queen, if a swam issues. So far as drones are concerned, it is far better to aroid their presence by having combs built from full sheets of foundation. The few drone cells then constructed around the edges will not produce enough drones to do any harm. Is a device for catching the queen when a swarm issues, it is successful, unless the queen chances to bo abnormally small.

$A$ word of caution regarding the use of the trap will not be amiss. It calls for attention and thought. It must frequently be freed of drones, else rentilation is obstructed and the colony may suffocate if weather conditions are right or shacle is lacking. Is a queen trap, it must be looked at crery day, or the queen may be caught and perish if too long confined or a storm occurs. Iany beekeepers have given up their use. 


\section{SMOKER.}

A good smoker is absolutely necessiry. Without one it is impossible to readily hanclle the bees under all the rarying conditions to be met with. Get one large enough. One having a barrel three and one-half inches in diameter is a good size, but if many bees are kept, a larger one will be found better. (Figure 10).

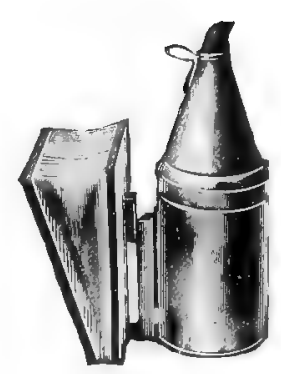

FIG. 10.-Smoker

\section{FOUNDATION FASTENERS.}

If one is using sections, some sort of a device must be used for fastening the foundation in the sections, and any one of the various

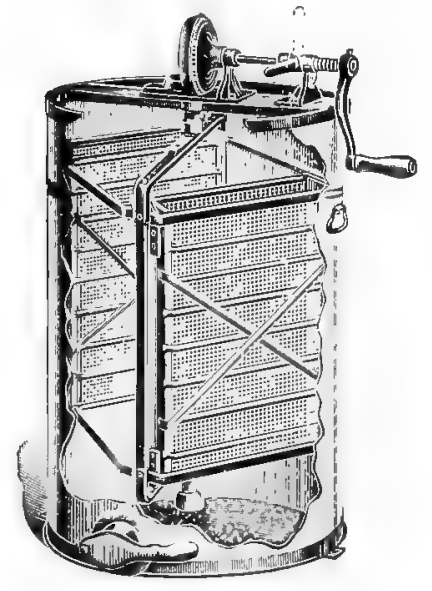

FIG. 11.-Extractor. machines using a heated metal plate will be found satisfactory. For only a few score sections a little melted wax may be used, but for rapid and extended work buy a fastener.

\section{HONEY EXTRACTOR.}

For extracted honey an extractor is necessary, and if much work of the kind is to be done, one of the "reversible" type will be found best. (Figure 11).

\section{HIVE TOOLS.}

For prying open hives, separating frames, etc., for scraping off wax and propolis, some sort of a tool is needed. A putty knife if fairly stiff is excellent, or one of the special tools sold for the purpose may be obtained. 


\section{COMB FOUNDATION.}

Comb foundation is beeswax made into thin sheets run through embossing rolls which give it the shape of the midrib of honey-comb with an outline of the cell walls. It is made in several thicknesses and of worker size colls, drone comb foundation only being furnished on special order. It is one of the clevices which the modern beekeeper cannot afford to do without. Drone comb has about four cells to the linear inch, while worker comb has five. (Figure 12).

In brood frames use the lighter grades of "Brood foundation" and wire the frames.

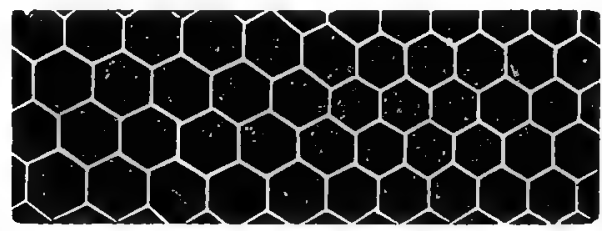

Drone Cellw. FIG. 12, Worker Cells.

In sections use the "light super" foundation until skilled in the art. The "extra light" sometimes bothers the novice. Many persons hesitate to use full sheets of foundation in the brood frames, deeming the sixty to seventy cents necessary for each ten frames an extravagance. It is a real economy, and the wisc beekeeper will never hesitate to make an expenditure in that line.

\section{CLOTHING.}

A veil for protecting the head from the bees is necessary. It may be purchased ready made or made at home from netting. The part used before the face should be black and preferably of silk tulle. The top may have an elastic cord run around it to slip over the hat crown or it may be sewed to the rim of a hat. Similar veils are made of wire cloth with a "skirt" of cotton cloth attached to the lower edge to tuck under the coat or to tie down. (Figure 13). 
Oftentimes the experienced beekeeper works without any veil, but one is always kept at hand in case the bees become irritated or cross.

Short gathered sleeves with elastic band in each end will be found excellent to keep bees from getting inside the coat sleeves. Rubber or leather gloves give confidence to the beginner, but will soon be discarded. Many other devices are offered for sale, but they are not necessary, and should not be purchased by the beginner.

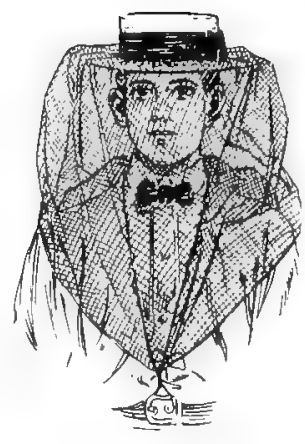

FIG. 13.-Bee Veil.

Light colored clothing of smooth texture, preferably of cotton, will be found better than rough woolens of dark color.

\section{UNIFORMITY OF APPLIANCES.}

Whatever type of hive is used be sure to have all alike, for unless all hives, frames, etc., are interchangeable endless trouble will ensue.

It is not wise to try to make one's own hives. Few persons have the tools or the skill necessary to produce a satisfactory article, and accuracy is essential. The vital principle of all movable comb beehives is the "bee-space," i. e., a space through which bees can pass and yet not so large as to induce them to build combs therein. A space through which they cannot pass they fill with propolis. Factory made hives have this detail carefully worked out.

Catalogues of dealers in beekeepers' supplies furnish full information on the various appliances.

The matter of hives and tools has seemingly perhaps been given undue attention, but unless the outfit is good the beckeeper will find much annoyance and needless labor, and unless he is a veteran, the troubles will make beekeeping so laborious and disagrecable that it is likely to be abandoned in disgust. It is true that honey may be obtained even though the bees are kept in an old box or hollow log, but profitable bee culture demands in suitable equipment. 


\section{MAKING A START.}

It is best to buy a good colony of bees in a standard hive, buying from some nearby beckeeper if possible. Also get for the first colony as gentle or easily-handled bees as the seller can furnish. If one's means warrant it, buy two such colonies, using one for study and experiment, and the other for honey, and as a reserve in case of disaster to the first, for frequent overhauling of a colony of bees is not conducive to its success or thrift.

It has sometimes been advised to start by buying bees in a box or any old hive and transfer them to a modern hive "for the experience." It is the sort of experience to dampen the ardor of the most enthusiastic, and an expericnce which a wise and thrifty veteran avoids as he would a pestilence.

\section{TIVE TO START.}

May and June are the most favorable months to make a beginning, but July or August will do, provided the novice does not try to increase the stock by division of the colonies. In buying earlicr than May, one is not so sure of obtaining a strong colony, and the desire to examine ancl orerhaul them may be irresistible, and is likely to prove disastrous to the bees. If purchased in September or October, little opportunity is offered for sturly, and about all that can be done is to see that sufficient food is in the combs for winter use. Winter is a most unwise time to buy bees, and even the skilled veteran avoids purchase then, unless he is thoroughly familiar with conditions as they were in the fall.

\section{BEES AND THEIR LIFE HISTORY.}

The more complete one's linowledge of the life and habits of the bees the easier and more rapid will be the progress in learning how to keep them and the better the chances for success. 


\section{THE QUEEN.}

The "queen," so-called, is merely the mother bee, and there is normally but one in a colony. She lays all the eggs from which the bees of the colony are produced. Upon her vigor and the virtues of her blood and mating depend the thrift of the colony. If she is old or failing, the colony dwindles. If her "blood" is not good her offspring cannot be expected to accomplish the results of offspring from a better bred queen. (See Figure 14).

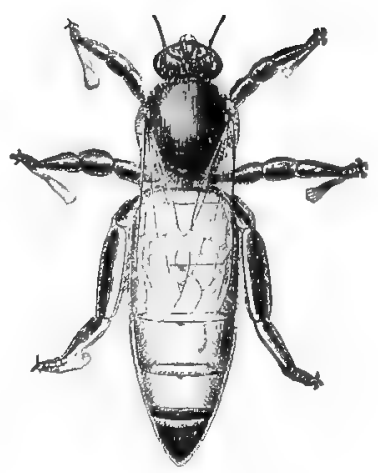

Fig. 11.-Queen.

A queen lives for several years, but as a rule is past her prime and period of greatest usefuln'ss after her second summer. There are exceptions to this, but the rule is a safe one to go by, and all queens should be replaced by young ones after the second summer. Mlany successful beekeepers re-queen all colonies each year.

\section{THE WORKERS.}

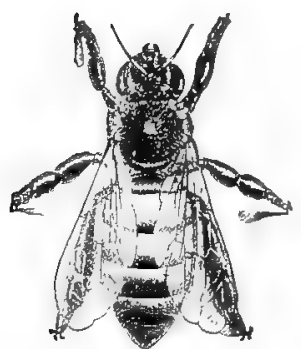

FIG. 15.-Worker.

These are the most numerous members of the colony. They are females, but with the reproductive organs not fully developed and only under some abnormal conditions do any of them lay eggs, such layers being termed "laying workers" and their eggs produce only drones (males).

The workers gather all the honey, pollen and propolis, secrete the wax, build the comb, maintain the heit of the colony, feed the larvæ and do all the work of the hive. They are also the oncs which do the stinging. (See Figure 15). 


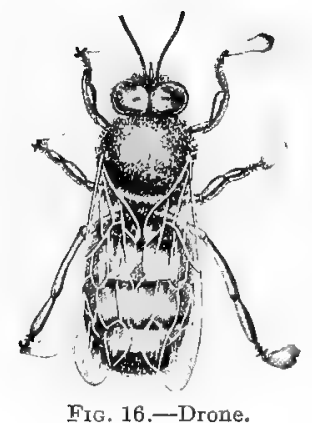

FIG. 16.-Drone.

\section{THE DRONES.}

These are the male bees and normally are produced only at such seasons as bees rear young queens and swarm. They have not the instinct nor are they constructed so they can work. Their sole known function is to perpetuate the race. They are much larger than workers or quecn and they have no sting. (See Figurs 16).

\section{BEE BEHAVIOR.}

The fundamental law of honey-bee life is co-operation. Though each individual goes about her work of her own volition, the results of her efforts are added to those of the rest of the colony.

The bees cluster in a more or less compact mass for mutual warmth, and when so clustered build their combs and care for their young. Within that cluster the temperature during the active season is close to $98^{\circ} \mathrm{F}$. The greater the number of bees the easier it is for them to maintilin throughout the hive the necessary temperature. If colonies are not populous, the bees have to cluster more compactly, the queen's room for laying is restricted, and cluring the harvest time the field forre may only be able to get food enough for themselves and the nurses and young.

In the winter a good colony of bees contains from 3,000 to 6,000 workers. Along about the first of January the queen begins to lay, slowly incretsing her laying as the season advances. As the young bees begin to emerge from the comb the queen becomes more active and, if cverthing is normal, by the time fruit trees bloom, the whole t'n combs will contain some brood, most of the combs being well fillcd. I colony in such condition is ready for the harvest.

If the inquisitive beekeeper frequently opens the hive in the spring, or kecps out combs unduly at that chilly season, abnormal conditions are produced and the colony will not be as strong or may even be destroyerl. 


\section{SWARMING.}

As the season progresses and the population of the hive increases, preparations for swarming may be made. Queen cells are built, (See Figure 17) and when the young qucens are nearly ready to hatch, the swarm emerges, usually on some sunny morning. They pour out like a torrent of living water and rapidly rising into the air, dart and circle about until finally they begin to gather on some limb or other object, and soon they are all clustered in a big irregular mass. If not taken down and hived they will seek some cavity and enter it. Within the

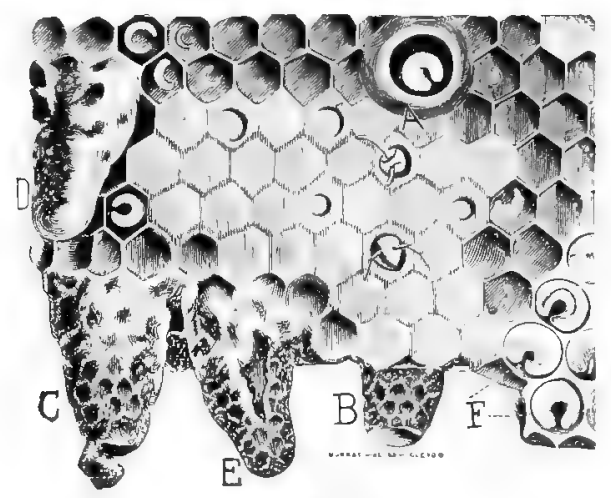

Fig. 17. Queen Cells.

hive or carity they again cluster and most of them remain very quiet. Slowly the wax scales push out from between the rings of the abdomen and are taken and worked into comb, which is soon occupied with eggs, pollen and honey.

Bees of most all ages go out with the swarm and the queen joins the throng usually when the swarm is about half out. If the queen fails to go with the swarm they will return to the parent hive.

If only a small part of the bees go out as a swarm, another swarm may follow when the young queens begin to hatch, or it may be delayed until the surviving young queen fies to mate.

Young queens mate about ten days after leaving the cell, though from adverse weather or scarcity of drones, it may be deferred for 
two or three weeks. As soon as mated the queen returns to the hive and within a day or two begins laying.

Ioung queens sometimes mate several times before they begin to lay, but after they commence to lay they never mate again. If a queen fails to mate she will ultimately begin to lay, but her eggs will produce only drones. These may be placed in worker comb, but as soon as the bees cap the brood the raised bullet-like cappings betray the sex of the contained young. Such a queen should be replaced with a good one.

The average time of incubation of the eggs is three days, though it varies with the temperature. From the eggs a minute white grub (larva) is hatched, and this is supplied with and lies in a millis white food prepared in the stomachs of the nurses from pollen and honey. It is fed thus for six days by which time it has grown until it fills the cell and it is then capped over and spins its cocoon and metamorphoses, turning from a grub into a bee as does the caterpillar into a butterfly.

The worker takes twelve days to make the change and the drone fifteen.

The "queen larve" receive a more abundant supply of the prepared food and take only seven days to change from grub to perfect bee. It is currently said that larvæ intended for queens receive a clifferent food from that given to the worker larve, but there are now good reasons for believing that it is quantity only that is varied, the chemical difference arising after it is put into the cells.

If the queen of a colony is removed intentionally or accidentally, the workers proceed to raise one or several more by enlarging some of the cells containing worker (female) larrat, and supplying the necessary food. In due time such indiviluals emerge as perfect queens. If the bees have neither eggs nor young larve they cannot raise a queen and unless the beckecuer supplics brood or a queen, the colony will perish. The bees rarely tolerate more than one laying queen in the hive at a time. Perhaps it were more correct to say that the queen rarely permits another cuen to remain long, for 
man can put in several queens and have each one laying for a time, but sooner or later all but one disappear.

\section{IMPORTANCE OF GOOD QUEENS.}

The success of the colony depends upon the queen, so it behooves the beckeeper to see that each colony has a young and vigorous one.

\section{INTRODUCING QUEENS.}

Introducing a new queen is a matter of much anxiety to the beginner. The first essential is to remove the old queen or if she is missing to be sure that no capped cell or young queen is present. Two methods of introduction are in common use, the "cage method" and the "direct." By the first, the queen is confined in a small cage usually with a few attendants, and the exit of the cage is plugged with a sort of candy made of powdered sugar and honey kneaded together. The cage is placel on top of the frames or between the combs and allowed to remain until the cancly has been eaten out and the queen freed.

The "direct method" consists of letting the queen run in free. It is helpful to confine the queen alone and without food for twenty to thirty minutes before running her in, in the meantime keeping her warm. The key to success in this method really lies in getting the bees of the colony to which the queen is to be given into a conclition of extreme distress or "fear." The experienced operator does this readily with smoke, and his ear quickly tells the "pitch" of the bees "roaring," which indicates the desired condition. When this is reached the queen is run in either at the entrance or on top of the frames, preferably at the latter place, and the hive quickly closed. She is immediately one of the mass of distressed bees each turning to the other for "help" and when the disturbance subsides she is quite as much at home as they are. A colony infested with laying workers will accept a queen run in in this way when they will not in any other, but unless they have been given a frame of un- 
sealed brood shortly before or soon after the queen is introduced, they not infrequently clestroy her in a few days or a week, or fail to properly feed the young. As a rule a colony containing laying workers is of too little value to try to save and should be united with some normal colony.

\section{CLIPPING QUEENS.}

For the convenience of the beckeeper at swarming time all queens should have their wings clipped. As the queens use their wings in holping themselves out of cells after laying it is not wise to cut both pairs of wings. It will be found sufficient and best to snip only the tips from the wings of one side. The queen may be able to fly a wry little, but not enough to enable her to go far or to rise to some inaccessible limb with the swarm.

\section{HANDLING BEES.}

Bees are more easily handled in the forenoon than later. At such times most of the field bees are out and the young bees in the hive are not as troublesome as the older or field bees. Very young bees, however, do sometimes have a faculty for running wildly over the combs, particularly when the older bees are present only in small numbers. This action often bothers a novice when he is trying to find a quecn.

\section{USING THE SMOKER.}

Oftentimes no smoke is necessary in handling bees, but it is a good rule never to open a hive without having a good supply of smoke available. Most anything which will burn will do for fuel in the smoker, but on most farms old burlap bagging which has been lying around in the open until it has begun to clecay is available in abunlance and makes ideal fuel. Ner or unrotted burlap does not kindle or burn at all well. Chips, partly kreayed rood, cotton waste or rags, or any similar substance, will do. Some beckeepers always begin with a puff of smoke at the entrance, others never use it there, and results seem to firror the latt'r'. After sturting the cover loose, 
a siight puff of smoke is blown under it, and then it is removed. If the bees show signs of "boiling up" over the tops of the frames, more smoke is blown over them from time to time. Not much smoke is needed, in fact, the beekeeper should study to see how little can be used.

\section{REIMOVING FRAMES.}

To remove a frame from the hive push back and remove the "division board" (follower), (Fig. 18), making room to spread the frames so as to give space to take out the desired one. If a little room is not thus secured, the bees are rolled over and over with the bees on the adjacent combs and much irritated, making work difficult and disagreeable for the beekeeper. "Ten-frame" hives

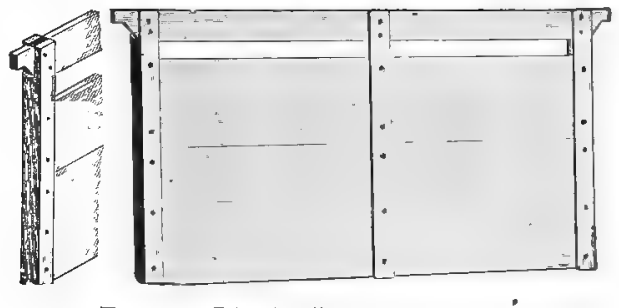

FIG. 18.-Division Board or Follower.

will not take ten frames and allow for such sliding back, so for easiest work nine frames and a division board (follower) are used.

Handle combs with quiet easy movements. Avoid quick, nervous motions or striking at bees. If stung scrape out the sting with knife or finger nail and blow a little smoke on the spot to hide the odor, as bees are excited by the odor of the bee poison and often follow up the first sting with others when it is not so treated. The veteran, however, gets more or less immune to bee stings, and unless they come thick and fast, pays but little attention to them.

If the bees get much excited and begin to dart at one's veil, burrow into the clothing and generally show signs of "anger," the hive should be closed as quickly as possible and operations deferred until some other day. 


\section{STINGS.}

Bee stings are rarely scrious unless received in great numbers. The pain is not long continued, and the swelling which (except on seasoned veterans) usually follows rarely remains for more than a couple of days. A little honey smeared over the injured spot will afford as much relief as anything. If you fail to appreciate your appearance after a sting or two on the fuce try to console yourself with the thought of the amusement it gives those who look at you, then grin-but not when anyone is looking.

\section{CAITION.}

Avoid handling becs on cold or wet days or on very windy days. Do not go prying into the brood nest of big colonies when they are busy piling up a surplus. Interference at such times is needless and detrimental, besides, a populous colony, for instance, one that is filling the body and several supers, is at diffeult thing for anyone but a skilled bee-master to pull to pieces, and he rarely cloes it if it can be avoided.

In handling combs alnays keep them "edge up." Do not turn them over "flat ways" or you may find them breaking from the frames.

Keep your colonies strong. This is old advice but good. Unless they are strong they will not give the best results. Vigorous queens will do more towards giving strong colonies than any possible fussing of the beekeeper. For Rhode Island it has been found that best results follow when the colonies are re-queened in August with queens which were reared in late July or early August. Also the colonies are not so populous then as earlicr and finding the old queen is easier.

\section{CNITING BEES.}

When honey is being gathered freely the bees of different colonies may be put trecther without any precaution, but at other times it maly be neresisily to get them into quite an uproar with smoke before uniting them. The uniting may le done by setting one hive 
body directly on another, letting the bees mingle at will; or the combs with bees on them may all be put in one body; or the bees may be shaken from the combs before a hive and allowed to crawl in. Queenless bees unite more readily than those having a queen. If one of the queens is not removed by the beekceper the bees attend to the matter, at least one quecn or the other is soon despatched.

\section{MOVING COLONIES.}

Do not change the location of the hives in the apiary after the bees have begun to fly in the spring, unless one of these two methods is followed: either moving but about a foot each day; or confining the bees to the hive and placing them in a cool cellar for three or four days and then liberating them at night and placing some obstruction, such as a bunch of grass or a bush, before the entrance. This assists in making them "take their location" when starting out the next day. When confined to the hives they should have wire cloth over the top of the hive and over the entrance. If the weather is hot, a sponge or roll of cloth saturated with water should be laicl on the wire.

\section{ROBBING.}

When working among the bees take pains not to spill any honey about or leave comb containing honey where the bees can get at it. Sweets so exposed may start robbing and this is particularly likely to occur if little or no food is to be found in the fields. Robbing once well under way is an unpleasant, even a serious matter. The easiest way the writer has found to stop it has been to put an abundance of syrup or honey a few rods from the apiary and get the bees started on it by walking among the hives with a comb of honey until it was well covered with bees and then gently carrying it to the food and leaving it. If enough food is put there to keep the bees busy until dark and the empty receptacles left there for the bees to smell over the next day, the evil is generally stopped without further trouble. 


\section{FEEDING.}

The bee master rarely has to feed his bees, but sometimes drouth or storm make it necessary to supply the bees with food to keep them alive or for their winter stores. The feeding is preferably done inside the hive. An empty body is placed on top of the brood chamber, and a number of fruit jars filled with syrup and their tops covered with checse cloth are inverted on the frames and the hive cover put on. The bees will take the food through the cloth. Be sure the cloths are tied on securely. I syrup, half sugar and half witer, stirred together until the sugar is dissolved is right. If the feeding is done in the fall when the weather is cool, have the syrup

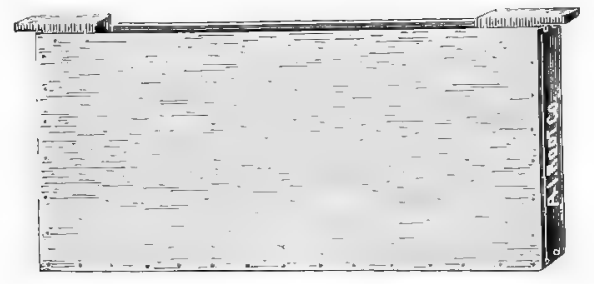

FIG. 19.-Division Board Feeder.

warm, say about $100^{\circ}$ to $120^{\circ}$ Feeding is preferably done near nightfall. For "winter stores" a colony needs about thirty pounds of honey or syrup. As the bees consume more or less of the syrup while moving it, it is usually necessity to feed about ten pounds more. Feeding for winter should be finished before the middle of October, preferably before the last of September.

Normally strong colonies re-queened in August will, with an abundance of stores, come out strong in the spring, and no "tinkering" in the way of stimulative feeding in the spring will help them. Various feeders are sold by the supply houses, the most convenient being the division board feeder. (Fig. 19.) The fruit jar will be found to meet most needs, however. 


\section{THE HONEY CROP.}

With strong colonies the securing of the honey crop is a relatively simple proposition. It may be tersely stated as putting on the supers and letting the bees alone. Put on the queen-excluding honey board and the "super" on top of that. If the beckeeper is away much or cannot see the bees for a week or more at a time, put on at the start all the super room thought necessary. Do not be afraid to give "too much." If the colony is properly strong it will use the space as it needs it. If it is convenient, give the supers when the first flowers open of the kind from which the surplus is gathered, as at the time of apple bloom, \&c. If not convenient to be on hand, then give them earlier.

Do not give supers to colonies which have not bees enough to fully cover the combs of the brood nest. Better unite two such colonies, making one strong one, and give that the supers.

In producing honey in "sections" it is desirable to remove them as soon as the bees have capped the combs in order to retain the whiteness of the cappings. As part of the combs are often finished sometime ahead of the rest, it is sometimes decmed wise to remove the supers, take out the finished sections, refill the supers with the partly filled sections and return them to the bees. The bee escape board is excellent for removing comb honey as the bees leave the combs quietly without cutting the cappings. Put on the escape boards near night and remove the honey in the morning. Usually only one super is removed from a hive at a time. If two or more are to be taken from one hive or if the weather is hot and close, it is often wise to slip nails or chips under the hive cover just enough to let the air circulate, but not enough to let bees pass.

In removing combs for extracting, the escape board may be used and is especially helpful to beginners. If it is not used, the combs are taken from the super or upper story one at a time, and the bees shaken or brushed from them either into the hive or in front of it, and the combs taken indoors. A bunch of asparagus tops or coarse grass 
makes an excellent brush. When it gets sticky throw it away and get a fresh one.

\section{EXTRACTING.}

$A$ best, extracting is a sticky and laborious job. It comes when the weather is hot and often when other work is pressing. It may, however, be deferred until some more convenient season, if one has plenty of surplus combs. Also the longer honey r'mains in the hive the richer and better it becomes. All one has to look out for is to get the crop of light-colored honey off before the dark honey begins to be gathered, and herein the value of knowledge of the honey yields (pasturage) of the locality becomes apparent.

After the combs are safely indoors they may be left in some warm and dry room shut up from bees and ants until it is convenient to extract, or the honey may be extracted at once and the emptied combs returned to the bees. Give such combs at as near night fall as possible. Combs fresh from the extractor create great excitement among the bees, and if given in the day time are liable to cause trouble.

\section{LNCAPPING.}

Cncapping the combs is done with a keen stiff-bladed knife, a butcher's knife with a twelve-inch blade is excellent. I pan or tub is used to catch the cappings. The frame rests on a strip of wood placed across the tub and while the frame is held by one hand, the other slices off the capping with a downward sawing stroke. Deep cutting clocs no harm as the bees quickly repair the combs.

If the honey is very thick or not very warm it may throw out very slowly. If so, throw it partly from one sicle, then all from the other, and then finish the first side. This procodure avoids crushing the combs into the wire baskets of the extractor.

For a limited amount of honey an extractor is not necessary. If the combs are newly built and are filled above a queen-excluding honey board, they will be free from young bees and contain little or no pollen, hence may be cut from the frames, crushed in a bag of 
strainer cloth and hung in some warm place to drain. This treatment may be given the cappings to obtain the honey mixed with them. After the honey has drained out, the comb is emptied into any convenient receptacle - except one of black iron or rusty tin-and melted and strained.

\section{SWARIMS AND THEIR TREATMENT.}

With all man's care and precautions bees seem prone to swarm just when it is least desired, which is when they are most busily at work gathering honey, and this seems particularly so when they are storing in sections. Shade, large entrances, an airy location, plenty of room for queen as well as for storage, all tend to deter swarming, but some always seem bound to swarm. About half the colonies in an apiary usually swarm under the systems mostly in vogue.

When the bees do swarm, if the queen was clipped she will be found on the grass or ground not far from the hive. She should be picked up and caged with a few of her workers. The hive should be set to the rear and another containing only frames with narrow starters of foundation put in its place. By this time the bees, not haring a queen with them, will be coming back. Lay the caged queen at the entrance while transferring the honey board and supers, with all the contained bees from the old to the new hive. Next shake all the bees from about half of the combs of the brood chamber of the old hive in front of the new one. In doing this have a wide board, hive cover or box placed level with the hive entrance to shake the bees on. When the majority of the bees are in, liberate the queen at the hive entrance and see that she goes in, using a puff of smoke if need be. Usually the bees will settle down to work again, and having no combs for storage below, will put all the honey above. Generally this is an excellent plan, but sometimes it does not rork, the bees trying to swarm again. If this occurs, re-cage the queen, and place the cage in the hive for a few days. If the beckeeper is not on hand to see the swarm, the bees, on missing the queen, will return to the hive. I few may find the queen in the grass and gather about her and thus 
indicate her whercabouts to the beekeeper. If she is not given back to the bees, or if the beekeeper is away and the queen perishes, the bees, after a day more or less of uneasiness, settle down to work again. If they have plenty of ventilation and storage room they rarely swarm with the young queen which succeeds the first swarming.

If the queen is not clipped and the swarm clusters where it can be reached, it is usually easiest to shake it into a basket or box, cover it with a cloth, carry it to the stand it came from, and when the new hive is ready, pour out the bees in front of and against the hive just as if they were so many beans. Keep empty hives which are awaiting swarms in some cool place or shaded. Bees do not readily enter hot hives.

\section{FORCED SWARMING.}

When a colony scems to be preparing to swarm, indicated by great population, starting of queen cells, bees hanging in masses on front of hive or about the entrance, it is the practice of some beekeepers to shake the bees from the combs, giving the bees a new hive on the old stand as in natural swarming, transferring to it the supers with the contained bees and giving the old brood chamber with its combs to some other colony to care for. Some vary this method by leaving about half the combs unshaken and placing the old hive at one side of the new. In a weck it is changed to the other side of the new hive, and a week later back again; this is to throw the force of young field bees into the "swamm."

Inother variation is to give the brood from which the "strarm" was shaken, to some watk colony, a week or so later de-queen it, and the next day shake most of the bees into or before the swarm. In foread swarming it is woll to make the "swarm" enter the new hive through a queen-excluding honey board temporarily placed under the hive body or through an "entrance guard" of excluder metal or through a drone trap. This shuts out all the drones. The queen is put inside the hive. It is wise to leave the guard or " $\mathrm{x}$ clucler board" in place for a few days, for "forced swarms" some- 
times get uneasy and "swarm out." As soon as they have settled down to work again the guard should be removed. The drones are kept out so as to aroid one disturbing element (as they are such when confined) and also to keep them from choking the entrance in their efforts to get out while the guard is on.

Forced swarming is profitably followed when treating colonies afflicted with any of the contagious diseases, except that the combs taken atray are not later shaken before the "swarm" for if they were, re-infection would be certain.

\section{REARING QUEENS.}

Excry beekeeper should raise his own queens and not depend upon the commercial queen breeders for anything but a new queen for breeding purposes.

The easiest way to secure a few young queens is to divide the combs of a colony that has swarmed into lots of twos or threes, seeing that each lot has one or more queen cells. Place these combs in empty hives, reduce the entrance so but one or two bees can pass, and plice the hives away from the large colonies, if convenient. In due time the young queens will hatch and mate and may then be used in desired.

Another simple way is to take a comb, preferably not a rery old one, put it in the midlde of the colony from the queen of which it is desired to raise new queens and five days later remove it. It will be found to be filled with eggs and very small larvæ. With a knife slice off a couple of inches or more from the lower part of the comb. This is to give the bees a better opportunity to build cells and also they will be built in a more convenient place for the beekeeper.

Place this comb with its adhering bees, but without the queen, in an empty hive and on rach sile of it place a comb containing. honey and pollen. Also give water in a division-board feeder or by a sponge. Now shake into this hive all the bees from two frames taken from the center of the same or of another good colony, being sure not to get the queen. Close the hive entrance with wire cloth and put 
the hive in the cellar or some moderately cool place for twenty-four hours, then set it out of doors, remove the wire and reduce the entrance. The liberation is prefereably done near nightfall.

Four clays after the first cell is sealed, form small colonies (nuclei) of a frame or two of brood and bec's, confine them as the cell building colony was treated, liberate them the next evening and give each little colony a sealed cell. To clo this easily, cut the cell from the comb together with a piece of the comb, say an inch square, and slightly separating two combs of the small colony (nucleus) place the call part way down betwecn them and push the combs together enough to hold it.

Two factors are important in raising queens, food and warmth. The first is secured by having an abundance of young bees (nurses), and the second hy the abundance of bers, reduced entrance, and if needs be, as during a cold storm, covering the hive with tarred paper or some similar method.

The hest qucens are generally raised in warm weather and during a good honey flow. If they are to be raised when little honey is to be found in the fields, fecding will be necesisary. It must be constant until the c'lls are sealed. T'se only sugar syrup for such feeding. Honey so used in liable to induce robbing.

\section{RACES OF BEES.}

If the bees one has are good workers and handle fairly well, it is wise to go slow in changing them. Most bees in Rhode Island are Blacks or Italians, or a mixture of the two. Some of the less common races have been introduced, but have soon become merged with the others. The Italian bee is probably the best all-round bee we have. The clifferent strains vary in color or work in slight clegree. If it is desired to change one's stock, buy a few queens, getting one or two each from different breeders. Try them out for a year and then breed from the best. The "leather-colored" Italians are to be preferred to the "yellow" or "golden" type. 


\section{INCREASE.}

If increase is not desired, the brood and remaining bees left by a swarm are united with some other colony after removing its queen or after destroying the queen cells in the hive the swarm left. If increase is desired, the old hive, now much reduced in numbers and without a queen, is placed on a new stand and looked at in about a fortnight to three weeks to see if the young queen is laying. With a good young queen it will soon become strong.

\section{ARTIFICIAL INCREASE.}

Colonies of bees may be divided into two or more parts, the old queen left with the part on the old stand and a new queen giren to the other part. The hives are filled out with combs or frames containing full sheets of foundation and the bees allowed to build up. This form of increase is excellent, but needs to be done with caution. It is best done during a good honey flow, but done then it puts an end to hope of surplus from the colonies treated. Indiscriminate division is unwise, and if a colony is divided into many parts, each may be too small to thrive, and the whole colony be lost.

Another excellent way to increase, but a little more laborious is to take a frame of brood with adhering bees from each of five or six colonies, put them together in one hive, fill out the empty space with combs or frames of foundation, and introduce a queen. If seven or eight frames of brood are taken this method may be used as late as the middle of September, but as a rule it is not wise to divide colonies after the middle of August. An expert may safely do it later but the beginner had better not try it.

\section{MARKETING HONEY.}

There are a few rules which should never be forgotten and should always be followed if one wishes to succed in the honey business:

First: Never sell or give away any unripe or ill-flavored honey. 
Second: Alwilys have the packages clean and free from stickiness. If in bottles, jars or cans, be sure they do not leak.

Third: If producing considerable quantities of honey and selling to stores or shipping it awaly have each case of comb honey all of one kind, and all sections as near as possible equally filled and capped. Have the honey of each lot in bottles of the same kind.

Sell first to your neighbors, next to the stores in your nearest town, and by the time your crops are too large for them to handle you will have learned where and how to sell large quantities. If you start supplying a store, try and reserve enough honey of the kind you start with to carry that customer through to the next season. Nothing so upsets the honey tracle as a change in the flavor of honey. Iany beekcepers are now practicing "blending" or mixing their various sorts of extracted honey so as to have it all of one general flavor. This is excellent practice, but requires experience for its greatest success. Strong flavored or very dark honeys must be scrupulously left out of such blends.

The best that can be done with comb honcy is to see that in each case all of the sections are of the same crop and endeavor to supply only one kind to one customer for the season.

When customers comment on the differences in flavor it is necessary to explain that the flavors of honey from different sorts of flowers vary as do the odors.

Extracted honey will granulate or crystallize in time, hence it is not wise to bottle at one time more than the customer is likely to dispose of before it begins to granulate.

In melting granulated honey heat it slowly and as soon as it softens stir it from time to time that it may heat uniformly. Be careful not to over-heat it or the flavor will be injured or spoiled, and the honey darkened. Ibout $130^{\circ} \mathrm{F}$. is as high as it is sufe to heat it.

\section{PREPARATIONS FOR WINTERING.}

There should begin in August with the re-queening of the colonies. If there is a dearth of nectar and the prospects of an immediate flow are 
slight, it is good policy to stimulate the production of brood. Probably the very best way to do this both for economy of labor and material and for the excellence of the results is to hang in each brood chamber one of the "division board" feeders (Fig. 19), filled with soft "Coffee $A$ " sugar. Do not add any water to it. This system was devised by Mr. Samuel Simmins, an eminent British beckeeper, and is one of the best things he ever gave to the public. The bees feed on the sugar just fast enough to keep the queen laying well. They do not store any of the liquified sugar in the combs.

$\mathrm{By}^{-}$the time the first frost cuts short the flowers, the colonies will be found to have a large population of young and vigorous bees. If the "fall flowers" did not yield enough to fill the combs well with honey the bees must be fed at once. Syrup of granulated sugar and water is the proper thing to use. Do not use "Brown" sugar. Make the syrup half sugar and half water, or if you have delayed too long, until the clay's as well as nights are cool, make it two-thirds sugar and one-third water. Feed enough so that the bees have not less than thirty pounds of stores. A Langstroth comb when filled contains about six pounds of honey, and in estimating supplies remember that brood combs contain much pollen and if hive and contents are weighed and from the gross weight the weight of a dry hive and set of combs are deducted, remember that old leathery or pollen-filled combs weigh very much more than new ones and that the bees weigh from three to six pounds or even more in a ver'y strong colony. Better give more than you think they need, and then some more.

Bees do not use much food in winter (sometimes as low as two pounds), but when they get right down to brood rearing in the spring, stores vanish like snow in the summer's sun. When all colonies are supplied with food, see that all covers are water tight, that the hives are level, or tilt slightly toward the entrance, fix the covers so they cannot blow off and then let them strictly alone until late spring. If mice are numerous it is a good plan to put across each hive entrance a piece of wire cloth with meshes large enough for bees to pass, but too small to admit mice. 
If single ply tarred paper or any other waterproof black paper is laich over each hive, folded down around the sides as one would do up a bundle and secured by strips of lath tacked along the lower edge, excellent protection is afforded both from moisture and from wind. Never close the entrance. It may be reduced in size, even down to a square inch, but the experience of years has shown that colonies with entrances wide open (i.e. 14 by 1 inch) are not only just as strong in the spring as those with reiluced entrances, but often stronger.

Attend carefully to this fall work to amount of fussing and feeding in the spring will make amends for neglect in the fall.

\section{CELLAR WINTERING.}

It is quite unnecessary to put bees in the cellar in this climate, in fact they are much better off out of doors. Some persons put them under sheds, packing all about mith leares or similar material. This is unwise as the hives get damp and the bees do not get the benefit of the sun and air. Leave them where they stood all summer, merely erecting some sort of a wind break if in an exposed place.

\section{ENEMIES.}

Bees have few real cnemies here. Skunks sometimes disturb them when the hives sit close to the ground. Ants not infrequently annoy them and occasionally become a real nuisance. They are readily destroyed by pouring gasoline into their nests, or the legs of the hive stands may be placed in tin can covers and a little crude oil or kerosene poured into each. Birds rarely disturb them. The king bircl or bee martin catches a few, but as these birds do so much good in devouring various noxious insects, we can well afford to give them a bee now and then. To a person engaged in commercial queen rearing a pair of king birds may become a decided pest, for they seem prone to catch the young queens. If shot at a few times with blank charges they rarely fail to change their hunting ground.

"Wrax moths" are often accused of killing out the bees. The bees 
whose hive becomes infested with the lirver of these moths will be found to be depleted in numbers through loss of the queen, disease, or some unfavorable circumstance. The strong colonies will quickly dislodge any they can reach. Weak colonies, however, seem discouraged and give up the struggle against them until ere long the combs are reduced to a mass of webs and dirt. When discovered in this condition, scraping the hive clean and burning all the refuse is all that can be done. The chief preventive to their inroads is to keep the colonies strong, by having a vigorous queen in each one.

Combs not in use should be stored in some dry room and inspected occasionally. If the "wax worms" appear, the combs should be fumigated with burning sulphur and returned to the room.

\section{DISEASES.}

There are two contagious diseases of bees now recognized, both of which attack the brood or bees in the larval stage, and are known respectively as American Foul Brood and European Foul Brood, the latter being sometimes called Black Brood. The so-called Pickled Brood is seldom met with and does not seem to be infectious. The term "foul" as applied to brood disease was given on account of the odor emanating from the dead brood. The larvie die in the cells and turn brown or black. The colony becomes depleted in numbers and unless treatment is prompt and thorough the disease will spread through and destroy the whole apiary.

In case of trouble or suspected disease, beekeepers are requested to write to the Entomological Department, State Board of Igriculture, State House, Providence, R. I., and the Apiary Inspector will render such aid as may be necessary. 



Rhan

\section{HOW TO KEEP BEES}

ARTHUR C. MILLER 




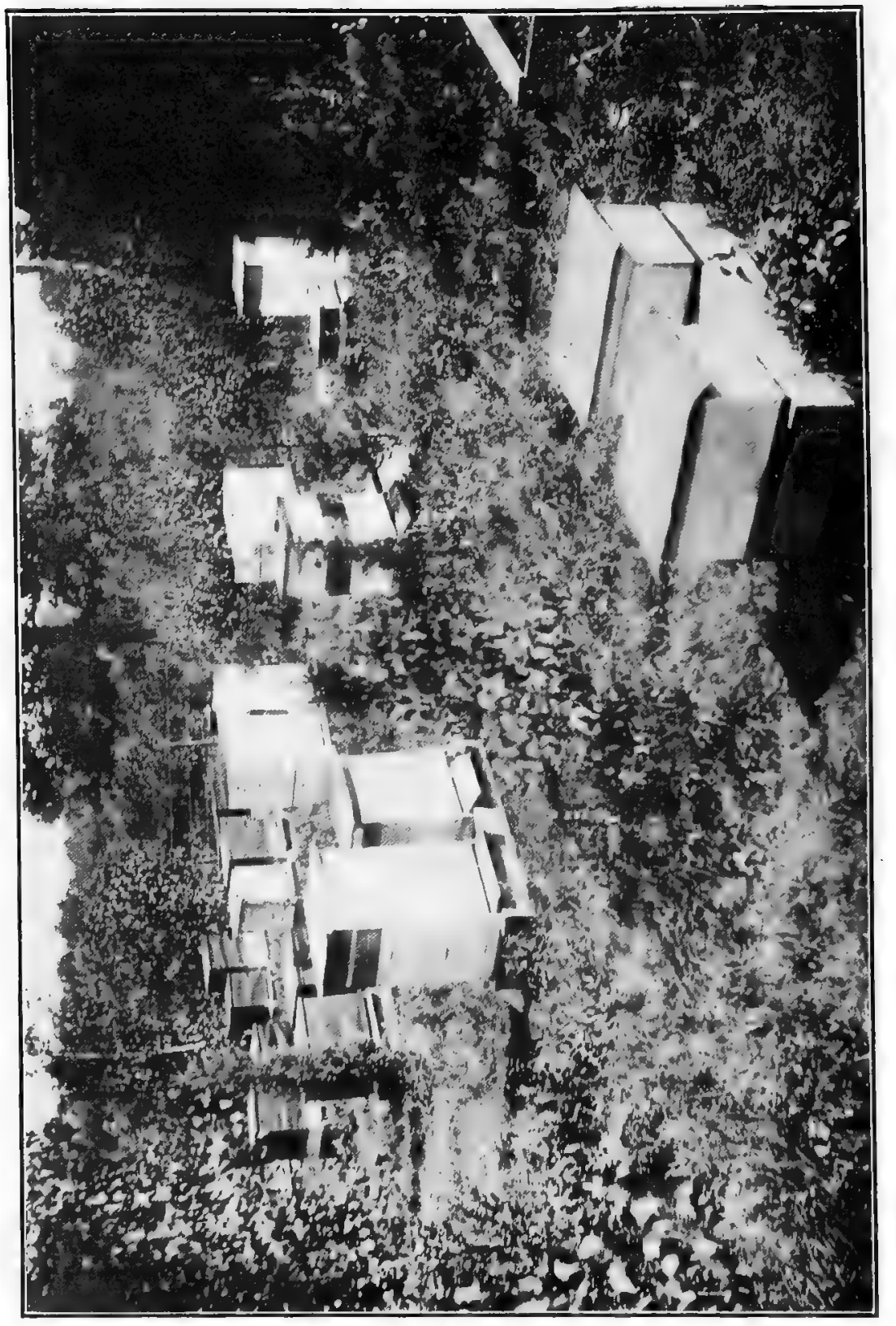

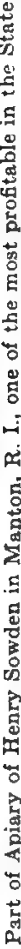




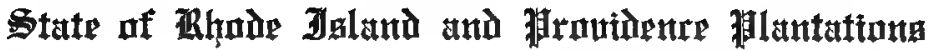

\section{STATE BOARD OF AGRICULTURE}

J. J. DUNN, Secretary

\section{Entomological Department}

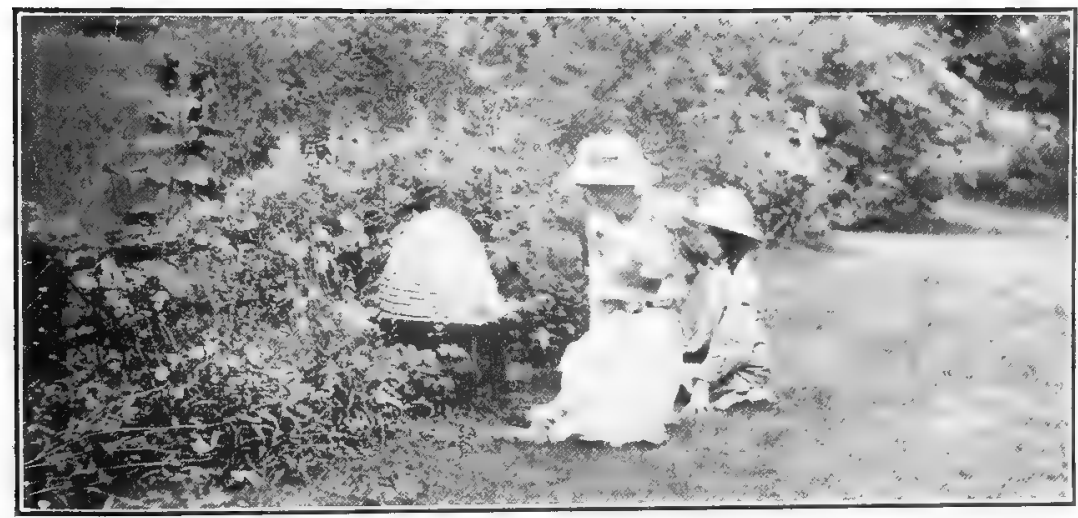

Old Fashioned Straw Hive at Linden Apiary of Miss Dorothy Quincy Wright, Chelmsford, Mass.

\section{HOW TO KEEP BEES \\ ARTHUR C. MILLER}

PROVIDENCE:

E. L. FREEMAN COMPANY, PRINTERS 


\section{Rhode Island State Board of Agriculture}

R. LIVINGSTON BEECKMAN,

Golerror.

EMERY J. SAN SOUCI,

Lieutenant Governor.

J. FRED PARIER,

Secretary of State.

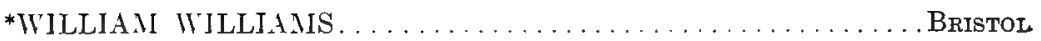

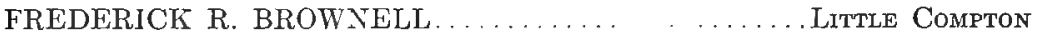
*THOMAS G. MLATHEWSON .... . ....... EASt Greenwich *I. L. SHERMAN.................. . . . BORDEN C. ANTHONY ......................... PoRTSMÖTH PHILIP A. MONEY ... . . . . . . . . . . . . . . . . SLOCUM W'jlljali E. Nicholi....... ...General Deliverx, Providence JOHN J. DUNN, Secretary.

* Executive Committee.

\section{Entomological Department}

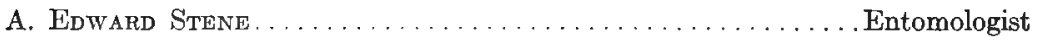
Arthur C. Miller . . . . . . . . . . . . . . . . . . Inspector of Apiaries J. J. Pillsbdry. . . . . . . . . . . . . . . . . . . Assistant Entomologist Harry Horovitz ............... Superintendent, Field Work 


\section{PREFACE}

Since the first edition of this bulletin was issued in 1911, there has been a considerable development in bee-keeping in Rhode Island, as well as other states, and the prospects are bright for a healthy and steady growth in the future. People generally are learning more and more to use and appreciate honey as a food and the demand is therefore growing. The possibility of keeping and tending a few swarms of bees to produce honey for home use even in small back yards, is becoming more fully known and the profitableness of larger ventures in the production of market honey is also being established.

While some of this development is due to an increase of interest in all lines of agriculture, and especially in such ventures to help reduce the high cost of living, which can be pursued on limited areas, such as a small back yard, nevertheless, I believe that a considerable part of it in Rhode Island comes as a result of the educational campaign carried on by Mr. Miller, under the auspices of the State Board of Agriculture through such publications as this bulletin, through lectures and through visits and demonstations in connection with the administration of the Apiary Inspection Law.

Before the advent of this work, bee-keepers had frequent disastrous experiences due to bee diseases, insect pests and a general lack of knowledge of bee-keeping which discouraged many of those already in the business and kept otters from attempting to enter the field. Mr. Miller has been able in connection with his inspection work to demonstrate how to effectively deal with most of the troubles with which the bee-keeper must cope and make bee-keeping an assured success instead of a partial or complete failure.

As stated in the preface to the first edition of this bulletin, the production of honey is a natural resource of comparatively limited extent when compared with some of the more staple agricultural products; nevertheless it is one which is easily developed and which is reasonably constant in its availability and which when fully. de- 
veloped, will add a great many thousands of dollars to the resources of the State. Furthermore, the gathering of honey by bees and other insects is a natural process on which many plants depend for the cross fertilization necessary to the best production of their fruits. For instance, it is becoming more and more patent to orchardists that in many cases the aid of bees is necessary to affect the cross fertilization required for the set and development of a good crop of apples and other orchard fruits.

Taking these and also other items not mentioned into consideration, it is evident that the further promotion of bee-keeping is a step in the right direction towards the development of our agricultural resources and towards reducing the high cost of living and increasing the health and well-being of the people of the state. The great demand for the first two bulletins written Mr. Mr. Miller and issued by the state Board of Agriculture, both of which have long since been exhausted, assures us that the present bulletin will meet a definite need and aid in the promotion of bee-keeping.

It is to be hoped aloo in connection with this campaign for beekeeping that a slight revision of the Bee Inspection Law may be achieved this coming year so as to bring it in line with the more recent derelopments in the processes of controlling hee diseases. And, finally, it may uot be amiss to express a hope that the beekeepers of the state will soon find it possible to organize a beekeepers' association, as already broached by Mr. Miller and others, which will have at least quarterly meetings for the discussion of their problems and for coopperating in the promotion of educational work relating to production, marketing and use of bee products.

The Board of Agriculture is indebted to the A. I. Root Co., Medina, O., for permission to use ruts for figures numbered 1 to 23 , and to the A. G. Woodman Co., Grand Rapids, Mich., for cut numbered 3-A, and to the W. T. Falconer MIfg. Co., Jamestown, N. Y., for eut of Air Space Hive (cut number 3-B).

A. E. STENE.

Providence, R. I., Dec. 14, 1917. 


\title{
HOW TO KEEP BEES
}

\author{
Arthur C. Miller, \\ Inspector of Apiaries.
}

\section{INTRODUCTION}

Since the first edition of this bulletin was issued bee-keeping in Rhode Island has progressed considerably. Several commercial apiaries have been established, numerous fruit growers have bought bees for the pollination of the bloom, and two men have established commercial queen rearing business which is proving a help to local bee-keepers.

Rhode Island offers excellent opportunities for profitable bee culture. The soil is diversified, the flora is varied and extensive, and the climate is not rigorous. Some of the more densely wooded parts of the State are not adlapted to the pursuit as a business, nor even adapted to the support of more than a few colonies here and there. Other parts, particularly those having considerable dairy farming and fruit growing, are well adapted to bee culture on a substantial scale and here and there are locations which compare favorably with the best in the land and will profitably support large apiaries.

The greater part of the Island of Rhode Island, the southerly part of Bristol County, the southwesterly part of the State bordering on Narragansett Bay and around the coast to the State line for one to five miles inland and several places adjacent to the Great Swamp are among the good locations referred to. 
Methods of bee culture have changed radically within recent years, apparatus has been improved and more nearly standardized and bee-keeping thereby made less laborious. To aid in extending bee-keeping in this State and to make it easier and more profitable are the objects of this bulletin.

\section{PASTURAGE.}

Bees may be kept almost anywhere, but to make them profitable several factors must be considered. The first and most important is the pasturage, for if that is not good, all the skill in the world will avail but little.

The sources of honey in Rhode Island grouped in the order of their appearance are willows, maples, elms and other less numerous trees which furnish the bees with the early supply of pollen and honey so useful and so needful in building up the bee population preparatory to the harvest in which the bee-keeper shares.

Next come the fruit blossoms, plum, peach, cherry, pear, apple, raspberries, huckleberries and blueberries which, when the spring is favorable, yield good crops of honey. In some places dandelions are an important addition to the fruit bloom, though not always coming at the same time. In several parts of the State there are large areas of locust. This blooms the latter part of May and when conditions favor, yields for about eight lays, a heary witer white honey. The clovers usually follow this, but are of consequence only under favorable conditions of rainfall, save in a few sections where soil conditions afford abundant moisture.

In many sections sumacs furnish the next crop, and where they are abundant the bee-keeper may rightly look for a good crop of a very fair honey.

In some of the more swampy and less settled sections, button bush, clethra (sweet pepper bush) and clematis yield a white and highly flavored honey; that from clematis being of the very highest quality. But the yield from these plants is irregular, in some years being almost absent. 
In some of the villages and cities the European. Lindens are numerous and yield heavily. The bloom comes toward the end of the clover flow, though the time of flowering of different trees in the same neighborhood varies greatly. Native Linden (Basswood) is now found only in a few places. The season closes with the goldenrods and asters, which yield a rich aromatic honey, which though not acceptable to many persons commands a fancy price from others. The crop from these two sources is not always to be depended upon, being more affected by the weather than some of the others.

Many other flowers contribute to the harvest, but seldom to any great extent.

It is important that the bee-keeper should know well the pasturage of his bees and govern himself accordingly. If the crop must depend only on one of the groups, he must needs bend every energy to get that, but if he has two or more to depend on he can vary his plans.

Bees range for food about two miles from home, but the best results are secured when the pasturage is within a mile or less of the apiary. Bear these facts in mind when seeking the location for an apiary and if already located, make a careful inspection of the country round about and determine the sources of supply.

\section{HONEY DEW.}

Honey dew, so-called, is a secretion of plant lice (aphids) and is deposited on the surface of the leaves. Some seasons it is very abundant and bees work on it eagerly. It varies in color from light gray to dark brown, is usually of unpleasant flavor, and is often bitter and spoils any honey with which it is mixed. All that the beekeeper can do is to remove all honey on the hives as soon as the gathering of honey dew is noticed, replacing the supers with others until the bees cease to gather it, when the supers of gcod honey can be returned and the stored honey dew saved and be given back to the bees during any slack period of the summer. It is not a good winter food for the bees. It should not be sold as honey. 


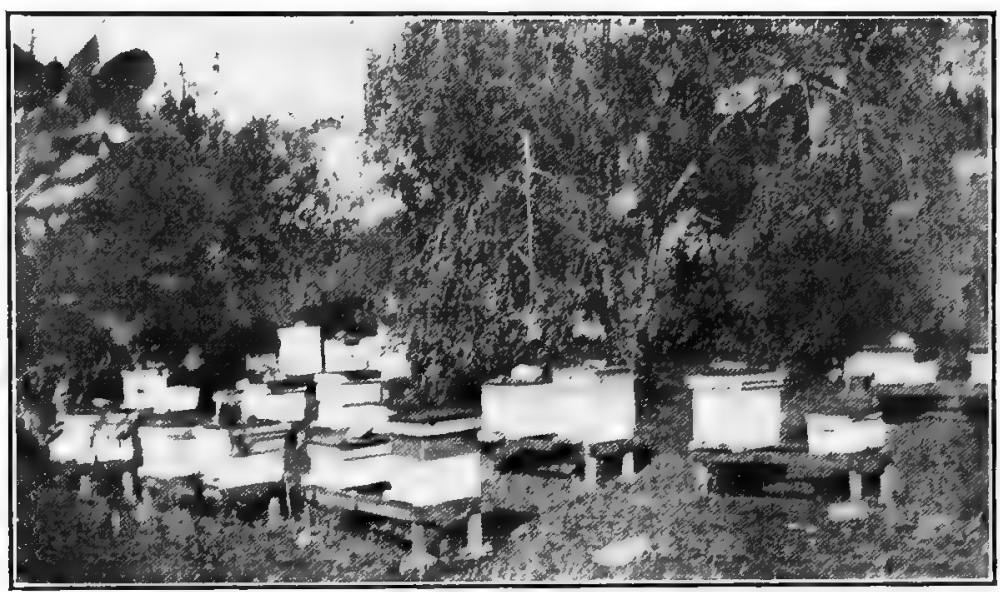

Apiary of G. B. Willis, Pontiac, R. I. (Moone's Cut.)

\section{LOCATION OF THE HIVES,}

The hives should be in a somewhat sheltered place, preferably where they get the morning sun and are shaded in the heat of the day. Avoid exposed windy locations. As the prevailing winds in the state are from the west and southwest it has been found advantageous to face the hive to the southeast or east. If on flat lands cr low lands, by all means raise the hives about a foot from the ground. It puts them abcve a strutum of cold fog which in the night often lies six or eight inches deep in such places.

Having the hives so raised will be found to be helpful in other ways. They are more convenient to work at, are up out of the grass, weeds and dirt, and where sundry vermin will not disturb them.

Any convenient thing will do to set the hives on, but a stand made of spruce fence-rails after the accompanying design has proved satisfactory in many years of service. The writer prefers a stand which will hold two hives and allow about eight inches between them. See Fig. 1.) So place the hives that the operator can stand beside or behind them. Putting them so it is necessary to work at the front is most undesirable. The legs of the stands should rest on pieces of thin 


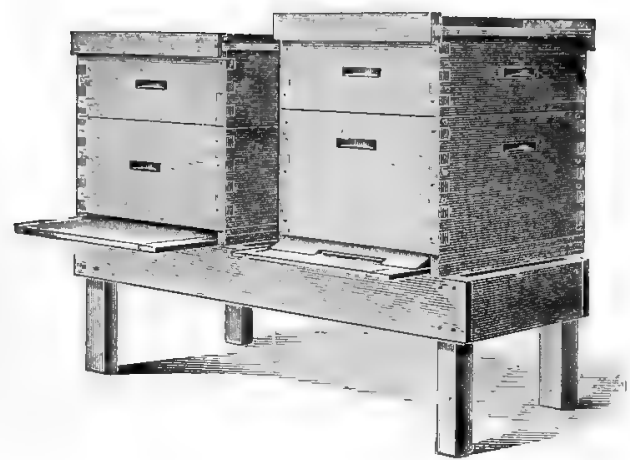

FIG. 1.-Hive Stand.

flat stone or brick to prevent their sinking into the ground and rotting and eventually allowing the hives to topple over under the load of a heavy crop.

Grass and weeds should be kept down and can be by heavy salting; or squares of asphalt roofing paper slightly larger than the stand may be laid on the ground before the stands are placed.

In cities and villages bees are often kept in. dwelling houses, being placed in some upper room and entrance given through a window or special passage cut through the walls.

\section{HIVES.}

Any of the hives commonly offered by the manufacturers of beekeepers supplies will do, but the more simple they are and the fewer the loose parts, the more satisfactory they will prove in the long run. Perhaps the most universal hive now in use is called the "Dovetailed" hive, named from the manner of its locked corners. (See Fig. 2.)

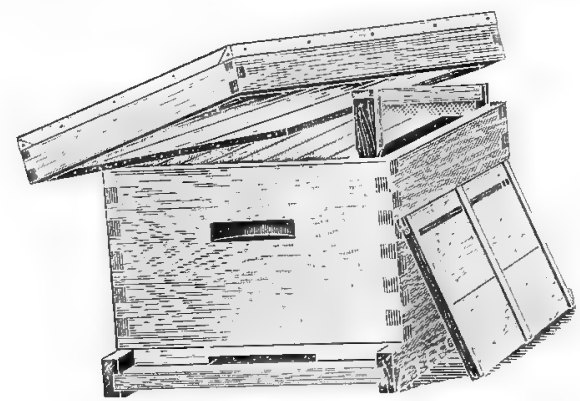

FIG. 2.-Dovetailed Hive. 
The hives known by this name all take the Langstroth frame, which measures $175 / 8$ by $91 / 8$ inches, outside measure.

These hives are commonly furnished in two widths called the eight-frame and the ten-frame. The former has had quite a vogue but is now rapidly being discarded for the ten-frame size, and the beginner should be sure to get the latter. The keeper of a few colonies who contemplates increasing should by all means change to the larger size. The type of cover shown in this illustration is one of the best commercial ones. A flat cover is always used inside of it. The "escape board" is sometimes used for this purpose, the escape being removed and the hole covered with a piece of thin wood. (Fig. 13.)

Hives having double walls with the space between filled with sawdust, etc., or merely a confined air space, have many advantages. (Cut 3-B.) The bees are less affected by sudden changes in the

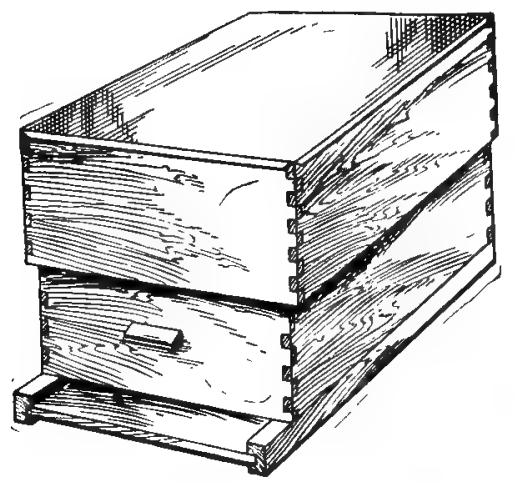

Fra 3-B.-Falcon Air Space Hive.

weather; they work in the supers better and need very little labor to prepare them for winter. These hives are excellent for the keeper of a few colonies and for orchardists and others who for want of time or knowledge neglect their bees more or less. They should be carefully nailed and rell oiled between walls when making up and the packing material should be something which will not readily absorb or hold moisture. Ground cork in which grapes are packed and obtainable from most any retailer of fruit is the best substance. 
The disadvantages of these hives is their weight, unwieldiness and for large apiaries the cost

- becomes quite an item. One of the best of this kind of hive is shown in Fig. 3-A. A simple outer case is used by some and answers the same purpose, but is not so convenient. It suffices for winter protection. Another type of outer case is shown in Fig. 25.

Hive floors are made so that one surface gives a $3 / 8$ inch space below the frames and the other gives a $7 / 8$ inch space. The latter

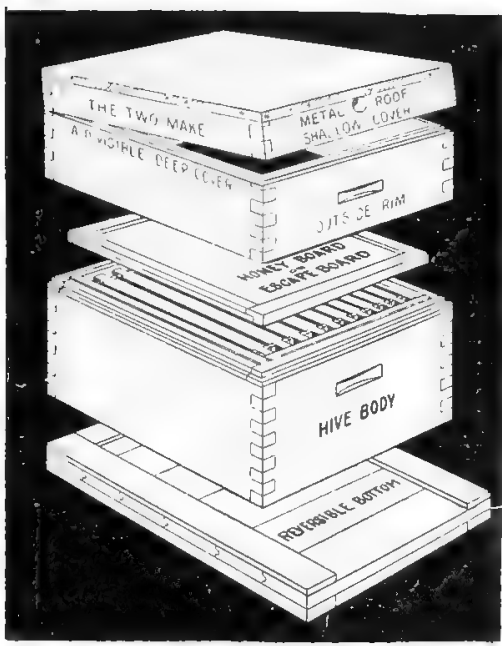

Fig. 3-A.-Woodman Protection Hive.

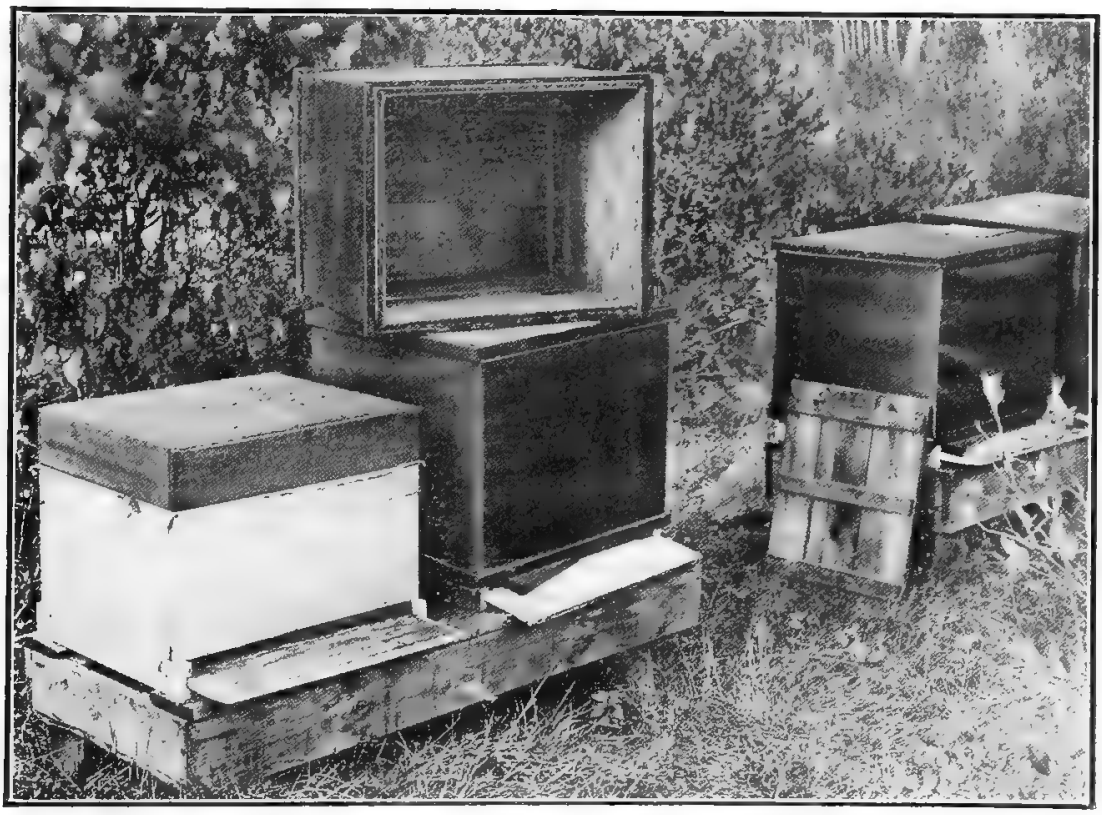

Fra. 25.-Protection afforded by sawdust filled tray and a deep cover which telescopes over all. Tray shown on hive at left and removed cover on top of hive at right. 
is to be preferred at all times. If a smaller entrance is desired reduce it with a notched stick such as is shown in the hives illustrated.

Hives of different sizes and proportions are used and advocated by different persons. They are designed to meet some supposed need of the bee-keeper, or are based on some theory of bee habits, but with one or two exceptions it is believed they all call for a lot of attention and manipulation at critical times. The average person will do well to avoid them. There is one type of hive, however which is designed to minimize labor and give average results. It has been the subject of so much discussion and so many inquiries have been made concerning it that it seems worth while describing it here. It is known as the "Let Alone" hive. The type was originally exploited lyy Gen. D. L. Adair, in the late '60's, and was then called the "Long Idea" hive. Some few years ago Mr. Allen Latham, of Norwich, Conn., experimented with it and finally developed the present type which he has called the "Let Alone." It is approximately thirty-six inches long, twenty inches wide, and eighteen inches high. In the Adair hive the entrance was in the middle of the long side, in the Latham hive it extends across one end. Mr. Latham had the advantage of an invention which Adair had not, namely, the so-called queen-excluding metal. Also Mr. Latham is a very careful student of bee habits, and with the knowledge acquired in many years' work with the bees, was able to accomplish what had not before been done.

In the Adair hive the queen had the run of all the combs (about twenty); in the Latham hive she is confined to the seven at the front, being kept from the others by a sheet of the queen-excluding metal. (Fig. 4.)

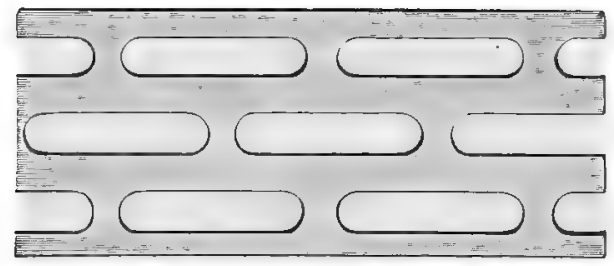

Fig. 4.-Excluder Metal. 
These are special hives which must be made to order. The frames are nearly five inches deeper than the standard Langstroth frame and these frames also have to be made to order. The top bars and end bars of the frames touch the whole length when the frames are in place in the hive, so that the bees can only pass out at the bottom. Beveled cleats are nailed along the lower inside corners of the hive and against these the bottom corners of the frames touch, keeping the bees from going behind the frames and virtually making a box within a box. The tops of the frames are about an inch below the top edge of the hive and Mr. Latham uses a few layers of newspapers and a thin wooden ccver on top of the frames. The cover proper has a three-inch rim and fits down over the hive. Hive body and cover are covered with heavy waterproof paper, black in color. The entrance which is an inch high, is guarded by a row of fine wire nails driven up through the floor. These are spaced far enough apart to permit the bees to pass freely and yet prevent the ingress of mice.

The bees and queen are started in the frames in the front end of the hive.and are thereafter seldom disturbed unless external appearances indicate something wrong inside. When the bees have the front or brood compartment filled they spread through the excluder metal into the space behind. The frames there have only "starters" of comb foundation as guides for the bees. At the convenience of the bee-keeper the honey in these frames is removed and the frames retưrned.

These hives are really the tools of a high class specialist, and while they will often succeed in the hands of a novice, their continued and uniform success on the minimum of labor plan calls for the knowledge only to be gained by long and careful observation of bees and their ways.

\section{FRAMES, SUPERS, ETC.}

Frames may be placed in two classes, free hanging and self spacing, and the latter again into hanging and standing. Probably the most extensively used and the best for the beginner are the self spacing frames of the Hoffman type illustrated here. (Figs. 5 and 6.) 


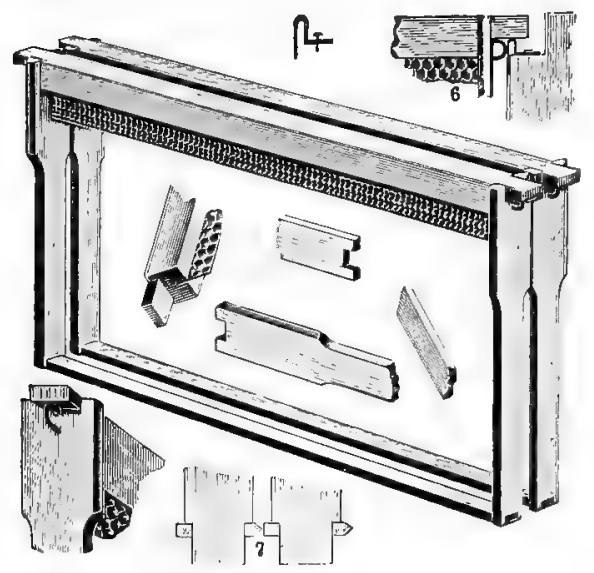

Fia. 5.-Self-Spacing Frame.

These frames have grooves in the top bar for fixing the comb foundation and holes in the end bars for wires. Fine tinned wire (No. 30 gage) is threaded through these holes, stretched tight and fastened. To these the sheets of foundation are fastened by embedding the wires in the wax. Various devices are sold for the purpose, but any narrow piece of iron with a shallow notch filed in the end will do. This is kept warm over an oil stove or lamp and is used by drawing the notch along the wire, bearing on just enough to bed the wire without cutting through the sheet of wax. In doing this work the frame is slipped over a board on which the foundation is laid.

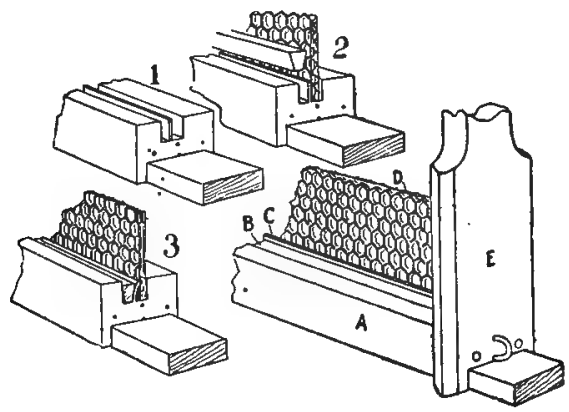

Fig. 6.-Showing manner of fastening Foundation in Frame. 
It is advisable to wire all brood frames as they may then be handled more readily, and if colonies of bees are shipped any distance, there will be no danger of wired combs breaking down.

"Shallow frames" are much like the others except that they are only from $4 \frac{1}{2}$ to $5 \frac{1}{2}$ inches deep. They are used in shallow chambers called supers, and the filled combs are either cut from them or uncapped, and the honey extracted. They are not usually wired. (Figs. 7 and 8.)

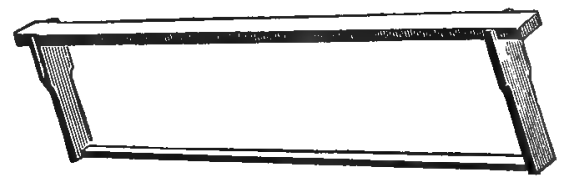

Fı. 7.-Shallow Extracting Frame.

Arrangements for producing honey in small boxes or "sections" are somewhat more complicated. The shallow chamber is much the same as above, but special holders are provided for carrying the

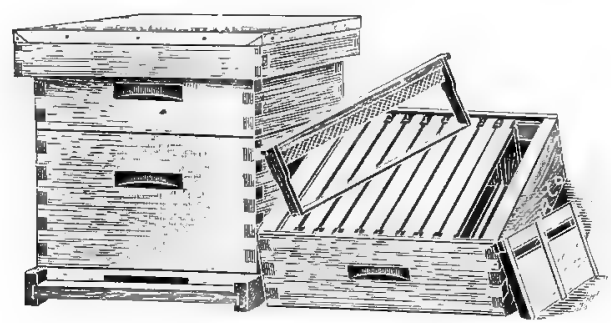

FrG. 8.-Hive with Shallow Extracting Super.

sections in which the bees build the combs. These are made of different widths and much trouble often ensues by failure to get sections to fit the bee-keeper's supers. Strips of thin wood separate each row of sections to prevent the bees bulging the surface of the combs. (Figs. 9 and 10.) 


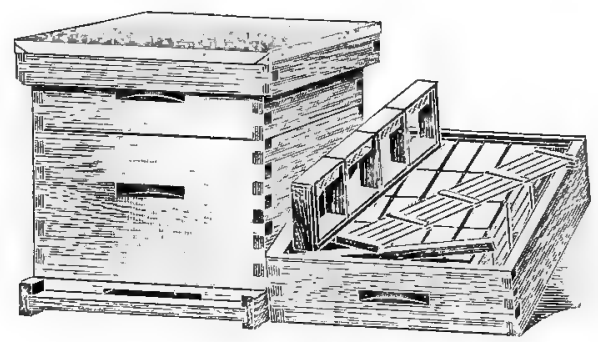

FIO. 9.-

\section{HONEY BOARDS.}

Honey boards, so-called, are devices for use between the body (brood chamber) of the hive and the surplus compartment (super). The most satisfactory one is made of slats between which are fixed

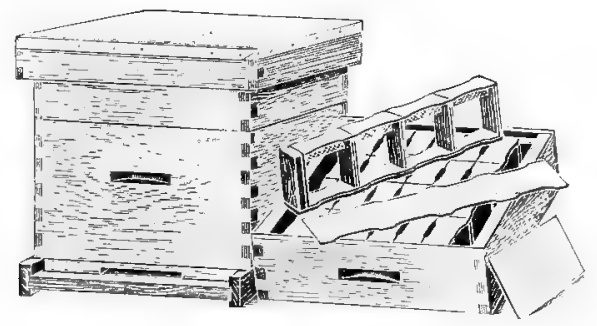

FIa 10.-

perforated strips of metal or accurately spaced wires to prevent the queen passing into the super. There is a rim around the edge so placed as to be flush on one surface and raised on the other, giving a bee space. The bee space side is used uppermost. (Fig. 11.)

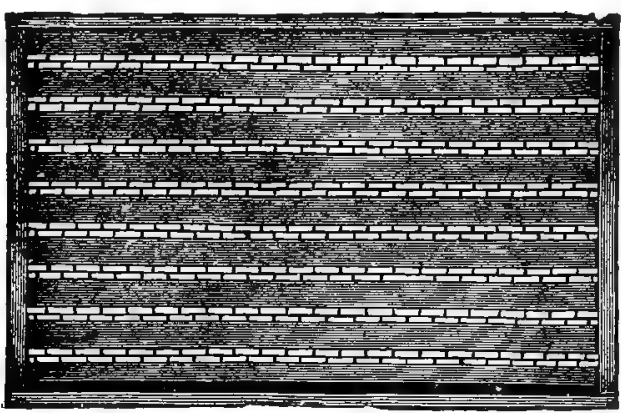

FIG. 11.-Honey Board. 


\section{BEE ESCAPES.}

A bee escape is a sort of fly trap device, permitting the passage of the bees in one direction only, and is used in a board placed between the brood chamber and the super to free the super from bees when

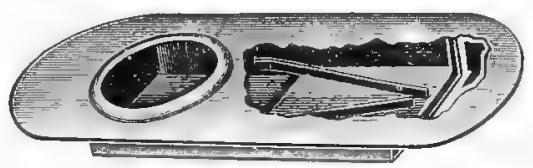

FIG. 12-Bee Escape.

it is desired to remove the honey. It is a most useful contrivance, but its success depends upon there being no brood in the "supers. (Figs. 12 and 13.)

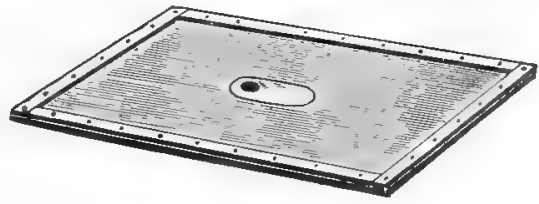

FIG. 13.-Bee Escape in Board.

These are improved by being "ventilated." Six or eight two-inch holes are bored through the board, or a narrow slot is cut the whole length of it and covered with wire screen cloth.

\section{DRONE AND QUEEN TRAP.}

The drone and queen trap is a two compartment box for use at the hive entrance to catch drones and the queen, if a swarm issues. So far as drones are concerned, it is far better to avoid their presence by having combs built from full sheets of foundation. The few drone cells then constructed around the edges will not produce enough drones to do any harm. As a device for catching the queen when a swarm issues, it is successful, unless the queen chances to be abnormally smatl.

A word of caution regarding the use of the trap will not be amiss. It calls for attention and thought. It must frequently be freed of 
drones, else ventilation is obstructed and the colony may suffocate if weather conditions are right or shade is lacking. As a queen trap, it must be looked at every day, or the queen may be caught and perish if too long confined or a storm occurs. Many bee-keepers have given up their use.

\section{SMOKER.}

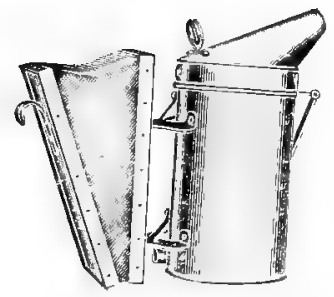

FIG. 1t,-Sinoker.

A good smoker is absolutely necessary. Without one it is impossible to readily handle the bees under all the varying conditions to be met with. Get one large enough. One having a barrel three and one-half inches in diameter is a good size, but if many bees are kept, a larger one will be found better. (Fig. 14.)

\section{SMOKER FUEL.}

Ise any material which will give a slow burning fire and yield an abundance of smoke when the bellows are worked. Dry rotten wood is a staple fuel, old burlap bagging is good, greasy waste gives an abundance of smoke, but is most unpleasant in odor. The writer finds dead wild cherry a delightful fuel to use. The dry dead twigs up to the size of one's finger snap like pipe stens and burn well. Larger limbs need to decay until easily broken with the hands. The smoke has a spicy odor, mild, swcet and most pleasant, and which rarely causes the eyes to smart. Be sure and have the fire well going in the smoker before beginning work with the bees. Keep a supply of dry fuel ready at hand and as soon as the smoker by blowing sparks shows signs of burning cut replenish it.

Perbaps no implement used by the bee-keeper is more misunderstood and misused than the smoker. With a good smoker and good fuel the skilled bee-man can handle the ugliest bees, without it the best bees may drive him off. 
Get a good smoker, oil the bellows leather, keep it under cover when not in use and it will remain good for years. Neglect it, and it will cause more trouble than a balky mule. When through using it put out the fire. Don't go off and leave it to burn out or it may start a serious fire.

\section{FOUNDATION FASTENERS.}

If one is using sections, some sort of a device must be used for fastening the foundation in the sections, and any one of the various machines using a heated metal plate will be found satisfactory. For only a few score sections a little melted wax may be used, but for rapid and extended work buy a fastener.

\section{HONEY EXTRACTOR.}

For extracted honey an extractcr is necessary, and if much work of the kind is to be done, one of the "reversible" type will be found best. (Fig. 15.)

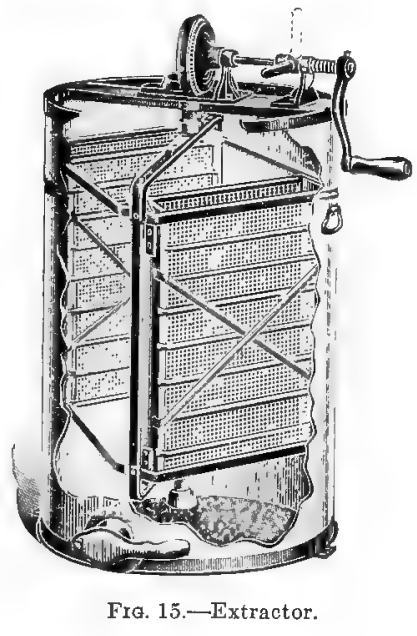

\section{UNCAPPING KNIFE.}

The special knives sold for this purpose have advantages peculiar to themselves, and where one has much such work to do, are worth while obtaining; but for a limited amount of work a good stiff butcher's knife with a blade about twelve inches long will do. Keep it sharp. (Fig. 16.)

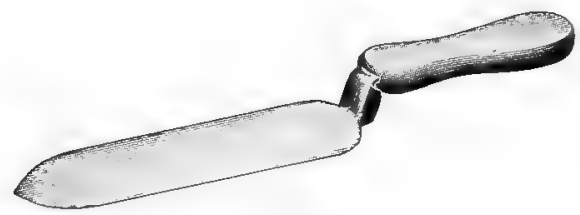

FIG. 16.-Uncapping Knife. 


\section{HIVE TOOLS.}

For prying open hives, separating frames, etc., for scraping off wax and propolis, some sort of a tool is needed. A stiff putty knife is excellent, or one of the special tocls sold for the purpose may be obtained.

\section{COMB FOUNDATION.}

Comb foundation is beeswax made into thin sheets run through embossing rolls which give it the shape of the midrib of honeycomb with an outline of the cell walls. It is made in several thicknesses and of worker size cells, drone comb foundation only being furnished on special order. It is one of the devices which the modern beekeeper cannot afford to do without. Drone comb has_about four cells to the linear inoh, while worker comb has five. (Fig. 17.)

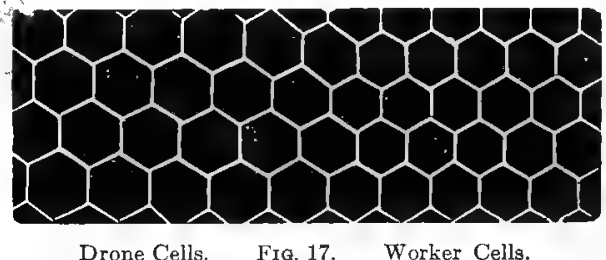

In brood frames use the lighter grades of "Brood foundation" and wire the frames.

In sections use the "light super" foundation until skilled in the art. The "extra light" sometimes bothers the novice. Many persons hesitate to use full sheets of foundation in the brood frames, deeming the sixty to seventy cents necessary for each ten frames an extravagance. It is real economy, and the wise bee-keeper will never hesitate to make an expenditure in that line.

\section{COMBS.}

Good ccmbs are the corner-stone of good bee-keeping. The appliances may be of the best, the bees the finest procurable, the location ideal, the management correct, and yet if the combs are pocr all the rest is wasted. 
To secure good ones wire the frames, stretch the wires till they hum like banjo strings, use full sheets of foundation and have the foundation built out in full colonies either by putting a body full of frames of foundation on as an upper story at a time when the bees are gathering freely from the fields, giving the queen access to the new story, or by placing the frames of foundation one at a time in the middle of a prosperous colony.

The writer esteems highly the Vogeler process of painting the foundation with melted wax after the foundation is fixed in the frames. A thin, flat brush, two or three inches wide is used, and melted wax "painted" lightly over the whole of each surface of the foundation. It stiffens the sheet, prevents "stretching," and produces splendid combs.

Some cells may be capped over in the process of painting and the foundation made to look somewhat daubed and spoilt, but trust the bees to put it right.

A little practice and experience will socn give the knowledge of the best temperature to keep the wax, the amount to use in the brush, and speed and pressure of the stroke. The results are worth all the effort it takes to get the knowledge.

\section{VEILS.}

A veil for protecting the head from the bees is necessary. It may be purchased ready made or made at home from netting. The part used before the face should be black and preferably of silk tulle. The top may have an elastic cord run around it to slip over the hat crown or it may be sewed to the rim of the hat. Similar veils are made of wire cloth with a skirt of cotton cloth attached to the lower edge to tuck under the coat or to tie down. They are more durable than those of net, but are heavier. (Fig. 18.)

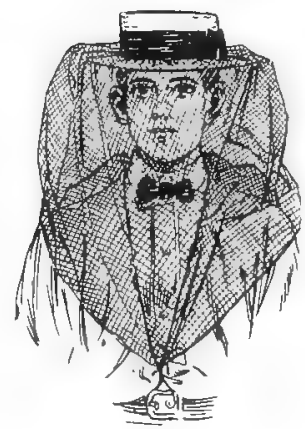

Frg. 18.-Bee Veil. 
Oftentimes the experienced bee-keeper works without any veil, but one is always kept at hand in case the bees become irritated or cross.

\section{GLOVES.}

Rubber or leather gloves give confidence to beginners. The oiled cotton ones offered by the supply houses do not appeal to the writer. Their fuzzy surface entangles the bees' feet, irritating them and causing the deposit of poison and then the trouble begins. Once well poison-odored and they are always assailed. One example will illustrate the trouble they cause. The writer was inspecting a dozen colonies of an amateur. The amateur wore veil and oiled cotton gloves, the writer was bareheaded and sleeves rolled to the elbow. The gloves had scores of angry bees busily stinging over them, no other part of the amateur was assailed and the writer got not a single sting.

Washing the hands over with a weak sclution of propolis (bee glue) in alcohol seals in the skin and also gives it a general hive odor which the bees seem to consider correct and seldom assail. Very thin shellac works in much the same way. Any strong washing powder will readily remove either mixture.

Short gathered sleeves with elastic cord in each end will be found excellent to keep bees from getting inside the coat or shirt sleeves.

\section{CLOTHING.}

Light colored clothing of smooth texture preferably of cotton will be found better than rough woolens of dark color. The khaki colored shirts and trousers are excellent. There is something about the dye used on blue overalls and jumpers that seems peculiarly irritating to bees, so do not use such garments for bee work when new or until they have been washed two or three times.

\section{UNIFORMITY OF APPLIANCES.}

Whatever type of hive is used be sure to have all alike, for unless all hives, frames, etc., are interchangeable, endless trouble will 
ensue. It is not wise to try to make one's own hives. Few persons have the tools or the skill necessary to produce a satisfactory article, and accuracy is essential. The vital principle of all movable comb beehives is the "bee-space," $i$. e., a space through which bees can pass and yet not so large as to induce them to build combs therein. It is approximately one-quarter of an inch. A space through which they cannot pass they fill with propolis. Factory made hives have this detail carefully worked out.

Insist on having all parts of the hive, covers, supers, floors, etc., made of white pine. Some dealers substitute cypress, an inferior wood for the purpose. The pine costs no more. If one dealer does not have it another will. Catalogues of dealers in bee-keepers' supplies furnish full information on the various appliances.

The matter of hives and tools has seemingly perhaps been given undue attention, but unless the outfit is good the bee-keeper will find much annoyance and needless labor, and unless he is an exception, the troubles will make bee-keeping so laborious and disagreeable that it is likely to be abandoned in disgust. It is true that honey may be obtained even though the bees are kept in an old box or hollow log, but profitable bee culture demands a suitable equipment.

\section{MAKING A START.}

It is best to buy a good colony of bees in a standard hive, buying from some nearby bee-keeper if possible. Also get for the first colony as gentle or easily-handled bees as the seller can furnish. If one's means warrant it, buy two such colonies, using one for study and experiment, and the other for honey, and as a reserve in case of disaster to the first, for frequent overhauling of a colony of bees is not conducive to its success or thrift.

It has sometimes been advised to start by buying bees in a box or any old hive and transfer them to a modern hive "for the experience." It is the sort of experience to dampen the ardor of the most enthusiastic, and an experience which a wise and thrifty veteran avoids as he would a pestilence. 


\section{TIME TO START.}

May and June are the most favorable months to make a beginning, but July or August will do, provided the novice does not try to increase the stock by division of the colonies. In buying earlier than May, one is not sure of obtaining a strong colony, and the desire to examine and overhaul them may be irresistible, and is likely to prove disastrous to the bees. If purchased in September or October, little opportunity is offered for study, and about all that can be done is to see that sufficient food is in the combs for winter use. Winter is a most unwise time to buy bees, and even the experienced bee-keeper avoids purchase then, unless he is thoroughly familiar with conditions as they were in the fall.

\section{BEES AND THEIR LIFE HISTORY.}

The more complete one's knowledge of the life and habits of the bees the easier and more rapid will be the progress in learning how to keep them and the better the chances for success.

\section{THE QUEEN.}

The "queen," so-called, is merely the mother bee, and there is

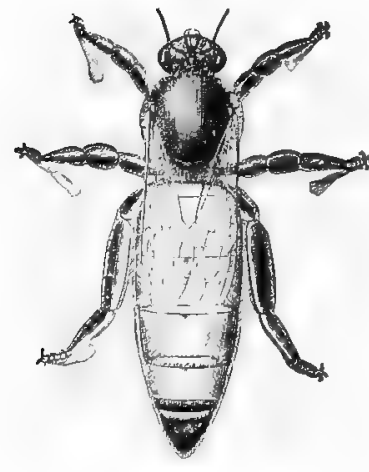

Fig. 19.-Queen. normally but one in a colony. (Fig. 19.) She lays all the eggs from which the bees of the colony are produced. Upon her vigor and the virtues of her blood and mating depend the thrift of the colony. If she is old or failing, the colony dwindles. If her "blood" is not good her offspring cannot be expected to accomplish the results of offspring from a better bred queen. She obtains most of her food direct from the workers.

A queen live for several years, but in a rule is past her prime and period of greatest usefulness after her second summer. There are 
exceptions to this, but the rule is a safe one to go by, and all queens should be replaced by young ones after the second summer. Many successful bee-keepers re-queen all colonies each year.

\section{THE WORKERS.}

These are the most numerous members of the colony. (Fig. 20.) They are females, but with the reproductive organs not fully developed, and only under some abnormal conditions do any of them lay eggs, such layers being termed "laying workers" and their eggs produce only drones (males).

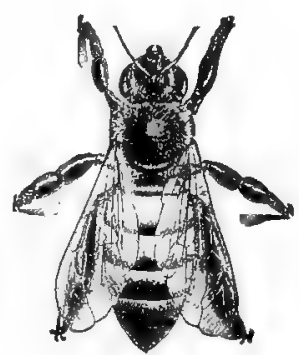

FIG. 20.-Worker.

The workers gather all the nectar, turn it into honey, gather the pollen and propolis, secrete the wax, build the comb, maintain the heat of the colony, feed the larvæ, and do all the work of the hive. They are also the ones which do the stinging. They live about ninety days during the busy season of the year. Those hatched in the fall live until the following spring.

\section{THE DRONES.}

These are the male bees and normally are produced only at such

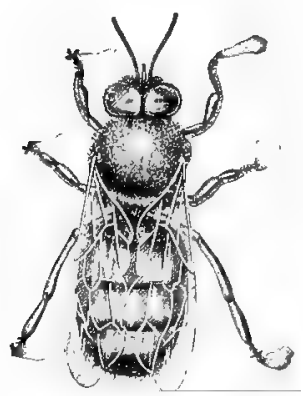

FIG. 21.-Drone. seasons as bees rear young queens and swarm. They have not the instinct nor are they constructed so they can work. Their sole known function is to perpetuate the race. They are much larger than workers or queen and they have no sting. They are dependent on the workers for food and when the latter want to get rid of them they refuse to feed them and drive them from the hive. (See Fig. 21.)

\section{BEE BEHAVIOR.}

The fundamental law of honey-bee life is coöperation. Though each individual goes about her work of her own volition, the results of her efforts are added to those of the rest of the colony. 
The bees cluster in a more or less compact mass for mutual warmth, and when so clustered build their combs and care for their young. Within that cluster the temperature during the active season is close to $98^{\circ} \mathrm{F}$. The greater the number of bees the easier it is for them to maintain throughout the hive the necessary temperature. If colonies are not populous the bees have to cluster more compactly, the queen's room for laying is restricted, and during the harvest time the field force may only be able to get food enough for themselves and the nurses and young.

In the winter a good colony of bees contains from 3,000 to 6,000 workers. Along about the first of January, in this latitude, the queen begins to lay, slowly increasing her laying as the season advances. As the young bees begin to emerge from the comb the queen becomes more active and, if everything is normal, by the time fruit trees bloom, the whole ten combs will contain some brood, most of the combs being well filled. A colony in such condition is ready for the harvest.

If the inquisitive bee-keeper frequently opens the hive in the spring, or keeps out combs unduly at that chilly season, abnormal conditions are produced and the colony will not be as strong or may even be destroyed.

\section{SWARMING.}

As the season progresses and the population of the hive increases, preparations for swarming may be made. Queen cells are built, and when the young queens are nearly ready to hatch, the swarm emerges, usually on some sunny morning. They pour out like a torrent of water and rapidly rising into the air, dart and circle about, finally beginning to gather on some limb or other object, and soon are all clustered in a big irregular mass. If not taken down and hived they will seek some cavity and enter it. Occasionally a swarm builds its combs to the limbs on which it clusters. It cannot survive the winter in such condition. Within the hive or cavity they again cluster, and most of them remain very quiet. Slowly the wax scales 
push out from between the rings of the abdomen and are taken and worked into comb, which is soon occupied with eggs, pollen and honey.

Bees of most all ages go out with the swarm and the queen joins the throng usually when the swarm is about half out. If the queen fails to go with the swarm they will return to the parent hive. IIf only a small part of the bees go out as a swarm, another swarm may follow when the young queens begin to hatch, or it may be delayed until the surviving young queen flies to mate.

Young queens mate about ten days after leaving the cell, though from adverse weather or scarcity of drones, it may be deferred for two or three weeks. As soon as mated the queen returns to the hive and within a day or two begins laying.

Young queens sometimes mate several times before they begin to lay, but after they commence to lay they never mate again. If a queen fails to mate she will ultimately begin to lay, but her eggs will produce only drones. These may be placed in worker comb, but as soon as the bees cap the brood the raised bullet-like cappings betray the sex of the contained young. Such a queen should be replaced with a good one.

The average time of incubation of the eggs is three days, though it varies with the temperature. From the egg a minute white grub (larva) is hatched, and this is supplied with and lies in a milky white food prepared by the nurses from pollen and honey. It is fed thus for six days by which time it has grown until it fills the cell and it is then capped over and spins its cocoon and metamorphoses, turning from a grub into a bee as does the caterpillar into a butterfly.

The worker takes twelve days to make the change and the drone fifteen.

The "queen larva" receives a more abundant supply of the prepared food and takes only six days to change from grub to perfect bee. It is currently said that larvæ intended for queens receive a different food from that given to the worker larvæ, but there are 
now good reasons for believing that it is quantity only that is varied, the chemical difference arising after it is put into the cells.

If the queen of a colony is removed intentionally or accidentally, the workers proceed to raise one or several more by enlarging some of the cells containing worker (female) larvæ, and supplying the necessary food. In due time such individuals emerge as perfect queens. If the bees have neither eggs nor young larvæ they cannot raise a queen and unless the bee-keeper supplies brood or a queen, the colony will perish. The bees rarely tolerate more than one laying queen in the hive at a time. Perhaps it were more correct to say that the queen rarely permits another queen to remain long, for man can put in several queens and have each one laying for a time, but sooner or later all but one disappear.

\section{IMPORTANCE OF GOOD QUEENS.}

The success of the colony depends upon the queen, so it behooves the bee-keeper to see that each colony has a young and vigorous one.

\section{INTRODUCING QUEENS.}

Introducing a new queen is a matter of much anxiety to the beginner. The first essential is to remove the old queen, or if she is missing, to be sure that no capped cell or young queen is present. Two methods of introduction are in common use, the "cage method" and the "direct" or "distress." By the first, the queen is confined in a small cage usually with a few attendants, and the exit of the cage is plugged with a sort of cancly made of powdered sugar and honey kneaded together. The cage is placed on top of the frames or between the combs and allowed to remain until the candy has been eaten out and the queen freed. Cages in which queens are sent by mail are so designed as to be used for introducing.

\section{DISTRESS METHOD.}

The "distress method" consists of putting the bees in a condition of "distress" and while they are in that condition, letting the queen 
run in among them. The procedure is this: See that the hive is smoke tight. If the cover does not fit snugly, remove it, lay two or three thickness of cloth or bagging over the top of the hive and replace the cover. If there are cracks at the corners of the hive, plug them with rags. Then nearly close the entrance of the hive with any convenient thing as grass, weeds or cloth, etc. Have the smoker going well, puff it until it sends out a cloud of thick white smoke, blow three or four puffs well inside of the entrance and completely close it. If the space below the frames is less than an inch it is often well to blow three or four puffs under the cover (under the bagging, if one has put that on), and then blow in at the entrance. In a few moments the bees will begin to "roar." At once let the queen run in at the entrance and reclose it, or open the end of the cage opposite to the food and lay the cage on top of the frames and shut all tight. The queen is immediately one of the mass of distressed bees each turning to the other for "help" and when the disturbance subsides she is quite as much at home as they are. In ten minutes after the queen is run in, about an inch of the entrance is opened, and the bees allowed to ventilate and quiet down. At the bee-keeper's convenience, after the bees are quiet, the rest of the entrance can be opened.

Some persons have failed with this method when the colony occupied two or more hive bodies, or when several supers were on owing to the difficulty of filling the hive with smoke. When a colony is as populous as that or as busy as that it is a very poor time to swap queens. Conditions, however, may be such that it becomes necessary to put in a queen at such a time, if so, lift off upper story or supers lay a sheet of newspaper on top of the lower brood chamber, replace the-upper story or supers and at once proceed to introduce the queen into the lower chamber. The bees will remove the paper in short order.

A colony infested with laying workers will accept a queen run in this way when they will not in any other, but unless they have been given a frame of unsealed brood shortly before or soon after the 
queen is introduced, they not infrequently destroy her in a few days or a week, or fail to properly feed the young. As a rule a colony containing laying workers is of too little value to try to save and should be united with some normal colony.

It is not necessary to destroy queen cells when introducing by the distress method, but if a virgin queen (young unmated queen) is in the hive she nill probably destroy the new one, or if conditions and season favor a swarm may issue.

\section{CLIPPING QUEENS.}

For the convenience of the bee-keeper at swarming time, all queens should have their wings clipped. As the queens use their wings in helping themselves into and out of cells when laying, it is not wise to cut both pairs of wings. It will be found sufficient and best to snip only the tips from the wings of one side. The queen may be able to fly a very little, but not enough to enable her to go far or to rise to some inaccessible limb with the swarm.

\section{HANDLING BEES.}

Bees are more easily handled in the forenoon than later. At such time most of the field bees are out and the young bees in the hive are not as troublesome as the older or field bees. Very young bees, however, do sometimes have a faculty for running wildly over the combs, particularly when the older bees are present only in small numbers. This action often bothers a novice when he is trying to find a queen.

An excellent practice followed by many bee-keepers is to look through every hive each spring, removing poor combs, scraping out all accumulation of propolis, substituting sound, well nailed bodies, floors, covers, etc., for any which may need repairs or paint. The procedure is to remove a colony from its stand and put in its place a clean floor and body and one by one lift the frames from the hive with the bees, scrape off the propolis and then put them into the clean hive. Keep the combs in the same order they occupied in the old hive. If any poor and unoccupied combs are removed add the 
new combs or frame of foundation at the outside of those with the bees. If the colony is short of stores or the queen is poor, it will be discovered during such an overhauling and be corrected. The foregoing method makes the subsequent work of the year much easier and pleasanter and keeps everything in good shape. Select a warm still day for this work and be careful not to drop the queen from the combs. Do the scraping over the old hive. When through, brush the few bees still clinging to it into the new hive, and if the old one is sound and does not need painting, scrape it out, clean the floor and use them for the next colony. If the queens are not clipped it is an excellent time to do it when doing this spring overhauling.

\section{USING THE SMOKER.}

Oftentimes no smoke is necessary in handling bees, but it is a gcod rule never to open a hive without having a good supply of smoke available. Some bee-keepers always begin with a puff of smoke at the entrance, others seldom use it there, and results seem to favor the latter. After starting the cover loose, a slight puff of smoke is blown under it, and then it is removed. If the bees show signs of "boiling up" over the tops of the frames, more smoke is blown over them from time to time. Not much smoke is needed, in fact, the bee-keeper should study to see how little can be used.

To get the bees under control at the start and keep them so is the secret of rapid and successful bee handling.

\section{REMOVING FRAMES.}

To remove a frame from the hive push back and remove the "division board" (sometimes called a follower or dummy), (Fig. 22),

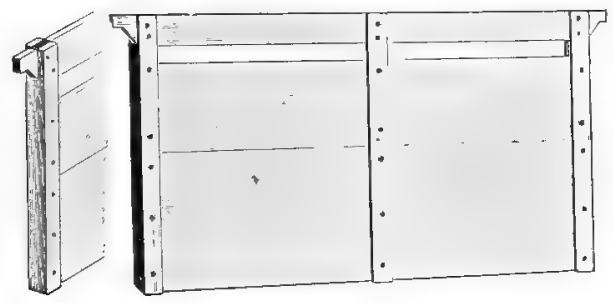

FIG. 22.-Division Board or Follower. 
making room to spread the frames so as to give space to take out the desired one. If a little room is not thus secured, the bees are rolled over and over with the bees on the adjacent combs, and much irritated, making work difficult and disagreeable for the bee-keeper. "Ten frame" hives will not take ten frames and allow for such sliding back, so for easiest work nine frames and a division board (follower) are used.

Handle combs with quiet easy movement. Avoid quick, nervous motions or striking at bees. If stung, scrape out the sting with knife or finger nail, and blow a little smoke on the spot to hide the odor, as bees are excited by the odor of the bee poison and often follow up the first sting with others when it is not so treated. The veteran, however, gets more or less immune to bee stings, and unless they come thick and fast, pays but little attention to them.

If the bees get much excited and begin to dart at one's veil, burrow into the clothing and generally show signs of "anger," the bive should be closed as quickly as possible and operations deferred until some other day.

In handling combs always keep them edge up. Do not turn them over "flat ways," or you may find them breaking from the frames if unwired.

\section{STINGS.}

Bee stings are rarely serious unless received in great numbers. The pain is not long continued, and the swelling which usually follows rarely remains for more than a couple of days. A little honey smeared over the injured spot will afford as much relief as anything. If you fail to appreciate your appearance after a sting or two on the face, try to console yourself with the thought of the amusement it gives those who look at you. Cultivate a sense of humor, it is a life preserver. Unfortunately some bee-keepers do not seem to know the meaning of the word. It is for us to laugh. 


\section{CAUTION.}

Avoid handling bees on cold or wet days or on very windy days. Do not go prying into the brood nest of big colonies when they are busy piling up a surplus. Interference at such times is needless and detrimental, besides, a populous colony, for instance, one that is filling the body and several supers, is a difficult thing for anyone but a skilled bee-master to pull to pieces, and he rarely does it if it can be avoided.

\section{STRONG COLONIES.}

Keep your colonies strong. This is old advice, but good. Unless they are strong they will not give the best results. Vigorous queens will do more towards giving strong colonies than any possible fussing of the bee-keeper. For Rhode Island it has been found that best results follow when the colonies are re-queened in August with queens which were reared in late July or early August. Also the colonies are not so populous then as earlier and finding the old queen is easier.

\section{UNITING BEES.}

When honey is being gathered freely the bees of different colonies may be put together without any precaution, but at other times it may be necessary to get them into quite an uproar with smoke before uniting them. The uniting may be done by setting one hive body directly on ancther, letting the bees mingle at will; or the combs with bees on them may all be put into one body; or the bees may be shaken from the combs onto a cloth or wide board placed before a hive and allowed to crawl in. Queenless bees unite more readily than those having a queen. If one of the queens is not removed by the bee-keeper the bees attend to the matter, at least one queen or the other is soon despatched.

\section{MOVING COLONIES.}

Do not change the location of the hives in the apiary after the bees have begun to fly in the spring, unless one of these two methods is 
followed: Either moving by about a foot or two each day; or confining the bees to the hive and placing them in a cool cellar for three or four days and then liberating them at night and placing some obstruction, such as a bunch of grass or a bush, before the entrance. This assists in making them "take their location" when starting out the next day. When confined to the hives they should have wire cloth over the top of the hive and over the entrance. If the weather is hot, a sponge or roll of cloth saturated with water should be laid on the wire.

\section{ROBBING.}

When working among the bees take pains not to spill any honey about or leave comb containing honey where the bees can get at it. Sweets so exposed may start robbing and this is particularly likely to occur if little or no food is to be found in the fields. Robbing once well under way is an unpleasant, even a serious matter. The easiest way the writer has found to stop it has been to put an abundance of thin syrup or diluted honey a few rods from the apiary and get the bees started on it by walking among the bives with a comb of honey until it was well covered with bees and then gently carrying it to the food and leaving it. If enough food is put there to keep the bees busy until dark (say two pounds for each colony), and the empty receptacles left there for the bees to smell over the next day, the evil is generally stopped without further trouble. But this is not a safe practice if bee diseases exist in the vicinty. Reducing the size of the entrance to an inch and smearing the hive front and floor near it with one of the creosote compounds will usually stop trouble unless it has been going too long.

In extreme cases close the hive with wire cloth put it in a cool cellar, supply it with food of thin sugar syrup and let it remain there for four or five days and when taken out put it in a new location.

Like many other evils it is more readily prevented than cured. 


\section{FEEDING.}

The bee master rarely has to feed his bees, but sometimes drouth or storm make it necessary to supply the bees with food to keep them alive or for their winter stores. The feeding is preferably done inside the hive. An empty body is placed on top of the brood chamber, and a number of fruit jars filled with syrup and their tops covered with fine cheese oloth are inverted on the frames and the hive cover put on. The bees will take the food through the cloth. Be sure the cloths are tied on securely. A syrup, half sugar and half water, stirred together until the sugar is dissolved is right. If the feeding is done in the fall when the weather is cool, have the syrup warm, say about $100^{\circ}$ to $120^{\circ}$. Also use a thicker syrup, two parts of sugar to one of water, either by measure or weight. Feeding is preferably done near nightfall. For "winter stores" a colony needs about thirty pounds of honey or syrup. As the bees consume more or less of the syrup while moving it, it is usually necessary to feed about ten pounds more. Feeding for winter should be finished before the middle of October preferably before the last of September.

Normally strong colonies re-queened in August will, with an abundance of stores, come out strong in the spring, and no "tinkering" in the way of stimulative feeding in the spring will help them. Various feeders are sold by the supply houses, the most convenient being the division bcard feeder. (Fig. 23.) The fruit jar will be found to meet most needs, however.

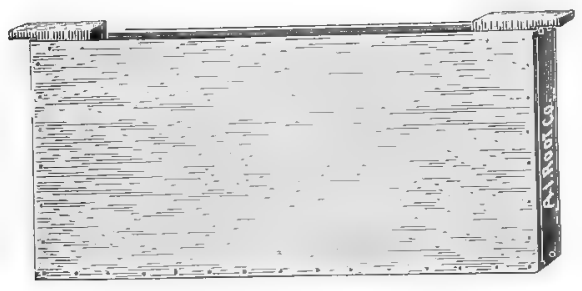

FIG. 23.-Division Board Feeder. 


\section{THE HONEY CROP.}

With strong colonies the securing of the honey crop is a relatively simple proposition. It may be tersely stated as putting on the supers and letting the bees alone. Put on the queen-excluding honey board and the super on top of that. If the bee-keeper is away much, or cannot see the bees for a week or more at a time, put on at the start all the super room thought necessary. Do not be afraid to give "too much." If the colony is properly strong it will use the space as it needs it. If it is convenient, give the supers when the first flowers open of the kind from which the surplus is gathered, as at the time of apple bloom, etc. If not convenient to be on hand then, give them earlier. Rather more satisfactory results are secured with extracting supers where eight frames are used in a ten-frame, super spacing them equidistant. The resulting combs are plump and easier to uncap.

Do not give supers to colonies which have not bees enough to fully cover the combs of the brood nest. Better unite two such colonies, making one strong one, and give that the supers.

In producing honey in sections it is desirable to remove them as soon as the bees have capper the combs in order to retain the whiteness of the cappings. As part of the combs are often finished sometime ahead of the rest, it is often cleemed wise to remove the supers, take out the finished sections, refill the supers with partly filled secticns and return them to the bees. The bee escape board is excellent for removing comb honey as the bees leave the combs quietly without cutting the cappings. Put on the escape boards near night and remove the honey in the morning. Usually only one super is removed from a hive at a time. If two or more are to be taken from one hive or if the weather is hot and close, it is often wise to slip nails or chips under the hive cover, just enough to let the air circulate, but not enough to let bees pass. Better still have the escape board ventilated. (Nee page 17.)

In removing combs for extracting, the escape board may be used and is especially helpful to beginners. If it is not used, the combs 
are taken from the super or upper story one at a time, and the bees shaken or brushed from them, either into the hive or in front of it, and the combs taken indoors. A bunch of asparagus tops or coarse grass makes an excellent brush. When it gets sticky throw it awaý and get a fresh one. If bee disease is in the apiary burn or bury the sticky grass or better still use a bee escape.

\section{EXTRACTING.}

At best, extracting is a sticky and laborious job. It comes when the weather is hot and often when other work is pressing. It may, however, be deferred until some more convenient season, if one has plenty of surplus combs. Also the longer honey remains in the hive the richer and better it becomes. All one has to look out for is to get the crop of light colored honey off before the dark honey begins to be gathered, and herein the value of knowledge of the honey yields (pasturage) of the locality becomes apparent.

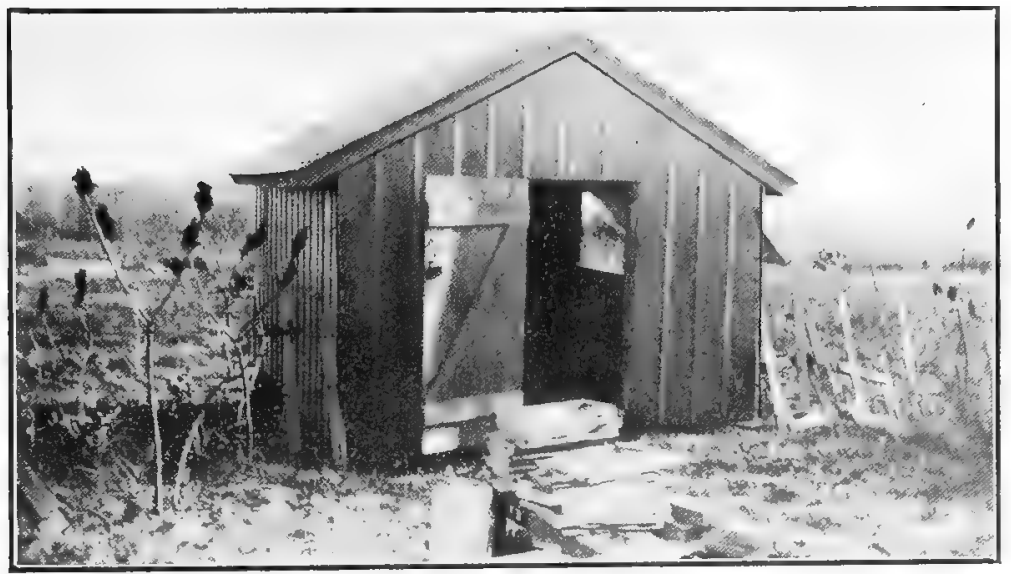

Fro. 24,-Extracting House at Hammond Hill, R I., 1916. Screened openings on each side give ample ventilation.

After the combs are safely indoors they may be left in some warm and dry rcom shut up from bees and ants until it is convenient to extract, or the honey may be extracted at once and the emptied combs returned to the bees. Give such combs at or as near night fall 
as possible. C'cmbs fresh from the extractor create great excitement among the luees, and if given in the day time are liable to cause trouble.

\section{UNCAPPING.}

Uncapping the combs is done with a keen stiff-bladed knife, an uncapping knife, or a butcher's knife with a twelve-inch blade is excellent. A pan or tub is used to catch the cappings The frame rests on a strip of wood placed across the tub and while the frame is held by one hand, the other slices off the capping with a downward sawing stroke. Deep cutting does no harm as the bees quickly repair the combs.

If the honey is very thick or not very warm it may throw out very slowly. If so, throw it partly from one side, then all from the other, and then finish the first side. This procedure avoids crushing the combs into the wire baskets of the extractor.

For a limited amount of honey an extractor is not necessary. If the combs are newly built and are filled above a queen-excluding honey board, they will be free from young bees and contain little or no pollen, hence may be cut from the frames, crushed in a bag of strainer cloth and hung in some warm place to drain. This treatment may be given the cappings to obtain the honey mixed with them. After the honey has drained out, the ccmb is emptied into any convenient receptacle - except one of black iron or rusty tinand melted and strained.

\section{SWARMS AND THEIR TREATMENT.}

With all man's care and precautions bees seem prone to swarm just when it is least desired, which is when they are most busily at work gathering honey, and this seems particularly so when they are storing in sections. Shade, large entrances, an airy location, plenty of room for queen as well as for storage, all tend to deter swarming, but some always seem bound to swarm. About half the colonies in an apiary usually swarm under the systems mostly in vogue. 
When the bees do swarm, if the queen was clipped she will be found on the grass or ground not far from the hive. She should be picked up and caged with a few of her workers. The hive should be set to the rear and another containing only frames with narrow starters of foundation put in its place. If tightly wired frames and full sheets of foundation painted with wax are available (page 21), these are preferable, but full sheets unwired will fall under the weight of a swarm. By this time the bees, not having a queen with them, will be coming back. Lay the caged queen at the entrance while transferring the honey board and supers, with all the contained bees from the old to the new hive. Next shake all the bees from about half of the combs of the brood chamber of the cld hive in front of the new cne. In doing this have a wide board, hive cover or box placed level with the hive entrance to shake the bees on. When the bees are marching in well liberate the queen at the hive entrance and see that she goes in, using a puff of smoke if need be. Usually the bees will settle down to work again, and having no combs for storage below, will put all the honey above. Generally this is an excellent plan, but sometimes it does not work, the bees trying to swarm again. If this occurs, re-cage the queen, and place the cage in the hive for a few days. If the bee-keeper is not on hand to see the swarm, the bees, on missing the queen, will return to the hive. A few may find the queen in the grass and gather about her and thus indicate her whereabouts to the bee-keeper. If she is not given back to the bees, or if the bee-keeper is away and the queen perishes, the bees, after a day more or less of uneasiness, settle down to work again. If they have plenty of ventilation and storage room they rarely swarm with the young queen which succeeds the first swarming.

If the queen is not clipped and the swarm clusters where it can be reached, it is usually easiest to shake it into a basket or box, cover it with a cloth, carry it to the stand it came from, and when the new hive is ready, pour out the bees in front of and against the hive just as if they were so many beans. Keep empty hives which are awaiting swarms in some cool place or shaded. Bees do not readily enter hot hives. 
If it is not known what hive a swarm issued from then hive it where it is found, and as soon as the bees are in or at night, remove it to the place where it is to stand permanently. Do not defer the moving for two or three days or so many bees will have marked the first location, that there will be a serious loss on moving them.

It is not necessary to put the hive up on a platform or step ladder near to where they clustered, until the swarm is all in. Put the hive on the ground, shake the swarm into a basket, and carry the bees to the hive. The mass of bees will set up a roar and emit an odor which will attract all the bees in the air and the few which go back to the tree will soon join those in the hive.

\section{FORCED SWARMING.}

When a colony seems to be preparing to swarm, indicated by great population, starting of queen cells, bees hanging in masses on front of hive or about the entrance, it is the practice of some bèe-keepers to shake the bees from the combs, giving the bees a new hive on the old stand as in natural swarming, transferring to it the supers with the contained bees and giving the old brood chamber with its combs to some other colony to care for. Some vary this method by leaving about half the combs unshaken and placing the old hive at one side of the new. In a week it is changed to the other side of the new hive, and a week later back again; this is to throw the force of young field bees into the "swarm."

Another variation is to give the brood from which the "swarm" was shaken, to some weak colony or one without supers, a week or so later de-queen it, and the next day shake most of the bees into or before the swarm. In forced swarming it is well to make the "swarm" enter the new hive through a queen-excluding honey board temporarily placed under the hive body or through an "entrance guard" of exclucler metal or through a drone trap. This shuts out all the drones. The queen is put insicle the hive. It is wise to leave the guard or "excluder board" in place for a few days, for "forced swarms" sometimes get uneasy and "swarm out." As soon as they 
have settled down to work again the guard should be removed. The drones are kept out so as to avoid one disturbing element (as they are such when confined), and also to keep them from choking the entrance in their efforts to get out while the guard is on.

Forced swarming is profitably followed when treating colonies afflicted with any of the ccntagious diseases, except that the ccmbs taken away are not later shaken before the "swarm" for if they were, re-infection would be certain.

\section{INCREASE.}

If increase is not desired, the brood and remaining bees left by a swarm are united with some other colony after removing its queen or after destroying the queen cells in the hive the swarm left. If inincrease is desired, the old hive, now much reduced in numbers and with out a queen, is placed on a new stand and looked at in about a fortnight to three weeks to see if the young queen is laying. With a good young queen it will soon become strong.

\section{ARTIFICIAL INCREASE.}

Colonies of bees may be divided into two or more parts, the old queen left with the part on the old stand and a new queen given to the other part. The hives are filled out with combs or frames containing full sheets of foundation and the bees allowed to build up. This form of increase is excellent, but needs to be done with caution. It is best done during a good honey flow, but done then it puts an end to hope of surplus from the cclonies treated.

Another excellent way to increase, but a little more laborious, is to take a frame of brood with adhering bees from each of five or six colonies, put them together in one hive, fill out the empty space with combs or frames of foundation, and introduce a queen. If seven or eight frames of brood are taken this method may be used as late as the middle of September, but as a rule it is not wise to divide colonies after the middle of July. An expert may safely do it later but the beginner had better not try it. Indiscriminate division is 
unwise, and if a colony is divided into many parts, each may be too small to thrive, and the whole colony be lost.

\section{REARING QUEENS.}

Every bee-keeper should raise his cwn queens and not depend upon the commercial queen breeders for anything but a new queen for breeding purposes.

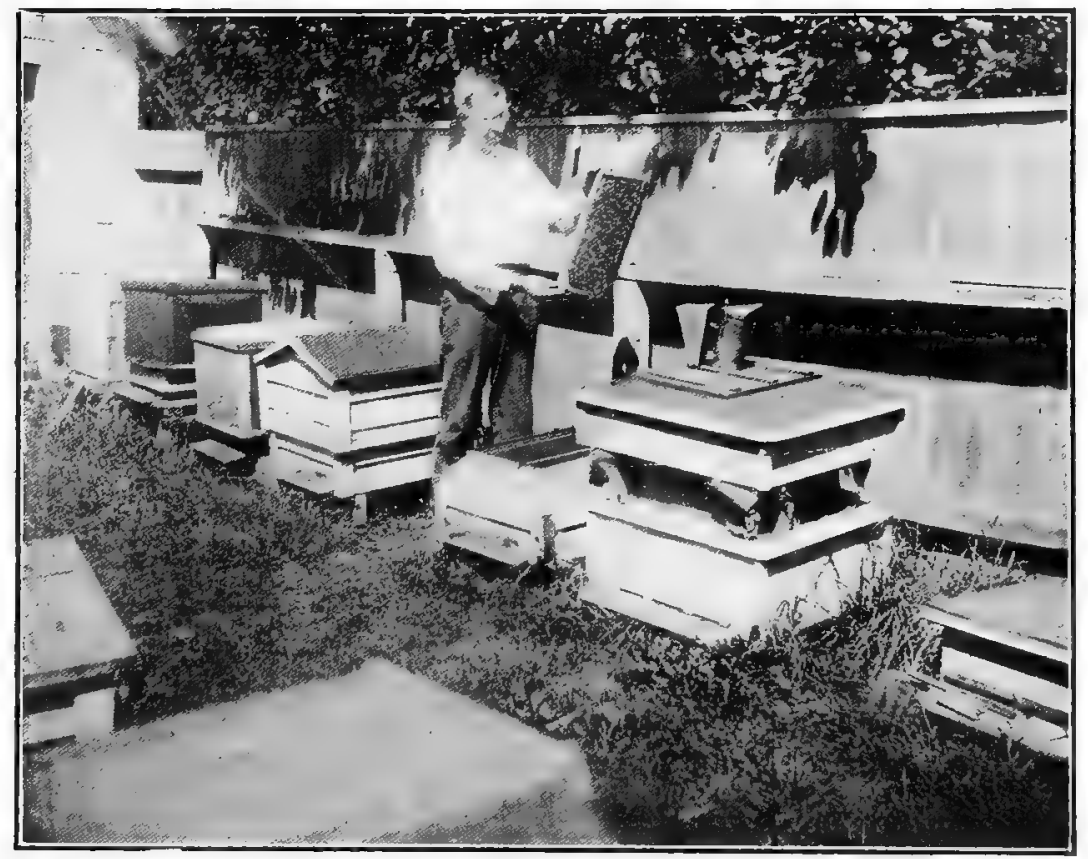

FIG. 27.-A Corner of a Rhode Island Queen Rearing Apiary.

The easiest way to secure a few young queens is to divide the combs of a colony that has swarmed into lots of twos or threes, seeing that each lot has one or more queen cells. Place these comls, with adhering bees in empty hives, reduce the entrance so but one or two bees can pass, and place the hives away from the large colonics, if convenient. In due time the young queens will hatch and mate and may then be used as desired. 
Another simple way is to take a ccmb, preferably not a very old one, put it in the middle of the colony from the queen of which it is desired to raise new queens and five days later remove it. It will be found to be filled with eggs and very small larvæ. With a knife slice off a couple of inches or more from the lower part of the comb. This is to give the bees a better opportunity to build cells and also they will be built in a more convenient place for the bee-keeper.

Place this comb with its adhering bees, but without the queen, in an empty hive and on each side of it place a comb containing honey and pollen. Also give water or thin sugar syrup in a division board or other feeder. Now shake into this hive all the bees from two frames taken from the center of the same or of another good colony, being sure not to get the queen. Close the hive entrance with wire cloth and put the hive in the cellar or some moderately cool place for twenty-four hours, and then set it out of doors, remove the wire and reduce the entrance so that only one or two bees can pass at a time. The liberation is preferably done near nightfall.

Three days after the first cell is sealed, form small colonies (nuclei) of a frame or two of brood and bees, confine them as the cell building colony was treated, liberate them the next evening and give each little colony a sealed cell. To do this easily, cut the cell from the comb together with a piece of the comb, say an inch square, and slightly separating two combs of the small colony (nucleus) place the cell part way down between them and push the combs together enough to hold it.

Handle queen cells very gently. Keep them right side up, do not expose them to the direct rays of the sun and if the day is cool prevent their being chilled.

Two factors are important in raising queens, larval food and warmth. The first is secured by having an abundance of young bees (nurses), and the second by the abundance of bees, reduced entrance, and if needs be, as during a cold storm, covering the hive with tarred paper or some similar method.

The best queens are generally raised in warm weather and during a good honey flow. If they are to be raised when little honey is to 
be found in the fields, feeding will be necessary. It must be constant until the cells are sealed. Use only sugar syrup for such feeding. Honey so used is liable to induce robbing.

\section{RACES OF BEES.}

If the bees one has are good workers and handle fairly well, it is wise to go slow in changing them. Nost bees in Rhode Island are Blacks or Italians, or a mixture of the two. Some of the less common races have been introduced, but have soon become merged with the others. The Italian bee is probably the best all-round bee we have The different strains vary in color or work in slight degree. If it is desired to change one's stock, buy a few queens, getting one or two each from different breeders. Try them out for a year and then breed from the best. The "leather-colored" Italians are to be preferred to the "yellow" or "golden" type.

\section{PREPARATIONS FOR WINTERING.}

These should begin in August with the re-queening of the colcnies. If there is a dearth of nectar and the prospects of an immediate flow are slight, it is good policy to stimulate the production of brood. Probably the very best way to do this both for economy of labor and material and for the excellence of the results is to hang in each brood chamber one of the "division board" feeders filled with soft sugar. Do not add any water to it. This system was devised by Mr. Samuel Simmins, an eminent British bee-keeper, and is one of the best things he ever gave to the public. The bees feed on the sugar just fast enough to keep the queen laying well. They do not stcre any of the liquified sugar in the combs.

Mr. Simmins used "raw" sugar, but several of the soft, moist, cream colored varieties found in most groceries do as well. Try samples until one is found which the bees use.

$\mathrm{By}$ the time the first frost cuts short the flowers, the colonies will be found to have a large population of young and vigorous bees. If the "fall flowers" did not yield enough to fill the combs well with 
honey the bees must be fed at once. Syrup of granulated sugar and water is the proper thing to use. Do not use "brown" sugar. Make the syrup half sugar and half water, or if you have delayed too long, until the days as well as nights are cool, make it two-thirds sugar and one-third water, and feed it hct. Fced enough so that the bees have not less than thirty pounds of stores. A Langstroth comb when filled contains about six pounds of honey, and in estimating supplies remember that brood combs contain much pollen and if hive and contents are weighed and from the gross weight the weight of a dry hive and set of combs are deducted, remember that old leathery or pollen-filled combs weigh very much more than new ones and that the bees weigh frcm three to six pounds or even more in a very strong colony. Better give more than you think they need, and then some more. Err on the safe side.

Bees do not use much food in winter (sometimes as low as two pounds), but when they get right down to brood rearing in the spring, stores vanish like snow in the summer's sun. When all colonies are supplied with food, lay across the tops of the frames two or three pieces of lath and cover the hive top with a piece of burlap or similar cloth. Put on an empty super or body and fill in with dry leaves or sawdust and put on the ccver. The protection on top of the frames is even mere important than that about the hive.

See that all covers are water tight, that the hives are level, or tilt slightly toward the entrance, fix the covers so they cannct blow off and then let the bees strictly alone until late spring. If mice are numerous it is a gocd plan tc put across each hive entrance a piece of wire clcth with meshes large encugh for bees to pass, but too small to admit mice.

A somewhat more convenient plan is shown in Fig. 25, where a wooden rim has burlap tacked on bottom and top and is filled with ground cork. An extra piece of burlap is laid cver the frames before this cushion is put on, so the bees will not cut through into the cushion and let the cork fall out. 
If single ply tarred paper or any other waterproof black paper is laid over each hive, folded down around the sides as one would do up a bundle and secured by strips of lath tacked along the lower edge, excellent protection is afforded both from moisture and from wind. Never close the entrance. It may be reduced in size, even down to a square inch, but perhaps an entrance six inches long by three-eighths inch high suits a wider range of winter conditions than most any other size.

Attend carefully to this fall work. No amount of fussing and feeding in the spring will make amends for neglect in the fall.

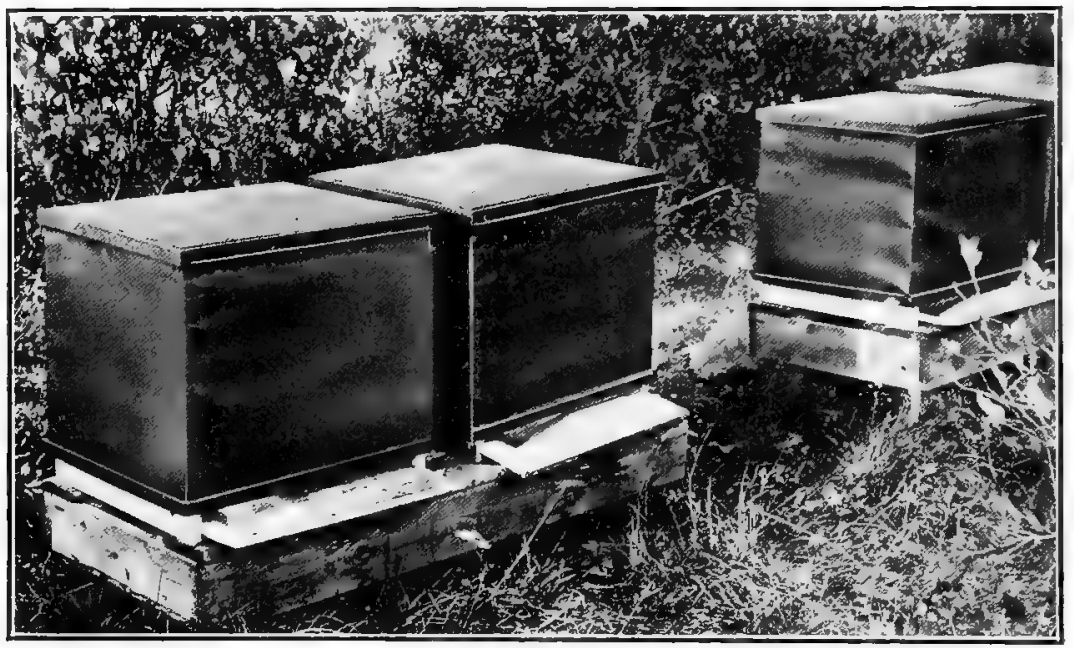

FIg. 26.

\section{CELLAR WINTERING.}

It is quite unnecessary to put bees in the cellar in this climate, in fact they are much better off out of doors. Some persons put them uncler sheds, packing all about with leaves or similar material. This is unwise as the hives get damp and the bees do not get the benefit of the sun and air. Leave them where they stood all summer, and erect some sort of a wind break if in an exposed place. 


\section{ENEMIES.}

Bees have few real enemies here. Skunks sometimes disturb them when the hives sit close to the ground. Ants not infrequently annoy them and occasionally become a real nuisance. They are readily destroyed by pouring gasoline into their nests, or the legs of the hive stands may be placed in tin can covers and a little crude oil or kerosene poured into each. Birds rarely disturb them. The king bird or bee martin catches a few, but as these birds do so much good in devouring various noxious insects, we can well afford to give them $a$ bee now and then, besides it is said they eat drones rather than workers. To a person engaged in commercial queen rearing a pair of king birds may become a decided pest, for they seem prone to catch the young queens. If shot at a few times with blank charges they rarely fail to change their hunting ground.

"Wax moths" are often accused of killing out the bees. The bees whose hive becomes infested with the larvæ of these moths will be found to be depleted in numbers through loss of the queen, disease, or some unfavorable circumstance. The strong colonies will quickly dislodge any they can reach. Weak colonies, however, seem discouraged and give up the struggle against them until ere long the combs are reduced to a mass of webs and dirt. When discovered in this condition, scraping the hive clean and burning all the refuse is all that can be done. The chief preventive to their inroads is to keep the colonies strong, by having a vigorcus queen in each one.

Italian bees keep out the wax moth much better than the Blacks.

Combs not in use should be stored in some dry room and inspected occasionally. If the "wax worms" appear, the combs should be fumigated with burning sulphur and returned to the room.

\section{MARKETING HONEY.}

There are a few rules which should never be forgotten and should always be followed if one wishes to suçceed in the honey business:

First: Never sell or give away any unripe or ill-flavored honey. 
Second: Always have the packages clean and free from stickiness. If in bottles, jars or cans, be sure they do not leak.

Third: If producing considerable quantities of honey and selling to stores or shipping it away have each case of comb honey all of one kind, and all sections as near as possible equally filled and capped.

Sell first to your neighbcrs, next to the stores in your nearest town, and by the time ycur crops are too large for them to handle you will have learned where and how to sell large quantities. If you start supplying a store, try and reserve enough honey of the kind you start with to carry that customer through to the next season. Nothing so upsets the honey trade as a change in flavor of honey. Many bee-keepers are now practicing "blending" or mixing their various sorts of extracted honey so as to have it all of one general flavor. This is excellent practice, but requires experience for its greatest success. itrong flavored or very dark honeys must be scrupulously left out of such blends.

The best that can be done with comb honey is to see that in each case all of the sections are of the same crop and endeavor to supply only one kind to one customer for the season.

IThen customers comment on the differences in flavor it is necessary to explain that the flarors of honey from different sorts of flowers vary as do their odors.

Extracted honey will granulitte or crystallize in time, hence it is not wise to bottle at one time more than the customer is likely to dispose of before it begins to granulate.

In melting granulated honey heat it slowly and as soon as it softens stir it from time to time that it may heat uniformly. Be careful not to over-heat it or the flavor will be injured or spoiled, and the honey darkened. About $130^{\circ} \mathrm{F}$. is as high as it is safe to heat it.

\section{DISEASES.}

There are three contagious diseases of bees now recognized, all of which attack the brood or bees in the larval stage, and are known respectively as American Foul Brood, European Foul Brood (the 
latter being sometimes called Black Brood), and Sac or Pickled Brood. The term "foul" as applied to brood disease was given on account of the odor emanating from the dead brood. The larvæ die in the cells and turn brown or black. The colony becomes depleted in numbers and unless treatment is prompt and thorough the disease will spread through and destroy the whole apiary. There has recently appeared a trouble among adult bees called "paralysis," in which the bees are unable to fly. Little is yet known about it.

In case of trouble or suspected disease, bee-keepers are requested to write to the Entomological Department, State Board of Agriculture, State House, Providence, R. I., and the Apiary Inspector will render such aid as may be necessary.

\section{THE BEE-KEEPER'S BOOKSHELF.}

Alexander, E. W. Writings on practical bee culture. Root, Medina, Ohio, $1910,50 \mathrm{c}$. A description of the author's practical methods in managing seven to eight hundred colonies in one yard, in eastern New York.

Comstock, A. B. How to keep bees. Doubleday, Garden City, L. I., 1905, $\$ 1.00$. A well illustrated handbook for the use of beginners, complete to the date of writing.

Edwardes, T. The lore of the honey-bee. Dutton, N. Y., 1911, 50c. Beekeeping and the literature and legends of the honey bee are traced briefly from the time of Virgil's Georgies to the present day. The wonders of the bee world are described with delicacy and charm.

Langstroth, L. I. On the hive and the honey-bee. Dadant, 1909, \$1.50. A classic in bee culture, clearly written and comprehensive.

Miller, C. C. Fifty years among the bees. Root, Medina, Ohio, 1911, $\$ 1.00$ Written from long personal experience in practical bee-keeping; illustrated from photographs. Dr. Miller is a comb-honey producing specialist.

Miller, C. C. A thousand answers to bee-keeping questions. American Bee Journal, Hamilton, 11l., 1917, $\$ 1.75$. (Compiled by Maurice G. Dadant.) Written in response to bee-keepers' queries, it covers a vast range of unusual subjects in interesting and illuminating terms. Illustrated. 
Pellett, F. C. Productive bee-keeping. Lippincott, Phila., 1916, \$1.50. A description of modern methods of the production and marketing of honey.

Phillips, E. F. Bee-keeping. Macmillan, N. Y., 1915, \$2.00. A comprehensive discussion of the life, habits, and manipulations of the honey-bee and of the production of honey.

Root, A. I. \& E. R. ABC and XYZ of bee culture. Root, Medina, Ohio, 1917, $\$ 2.50$. A splendid cyclopedia of everything pertaining to the care of the honey-bee, with many pictures. Enlarged and brought up to date by frequent revision.

Townsend, E. D. The Townsend bee book. Root, Medina, Ohio, 1910, 50c. The author tells how he began to keep bees and gives full and practical advice to others.

WrIGHT, W. D. The honey-bee. Albany, 1913. (N. Y. Department of Agriculture Bulletin 49. Address, Commissioner of Agriculture, Albany, N. Y.) A fully illustrated pamphlet treating of bee-keeping on a commercial scale.

Farmers' Bulletins, Experiment Station Publications, etc.

Desirable publications are issued by the Federal and State governments. Write to your Congressman at Washington, D. C., your own State Board of Agriculture, and Agricultural Experiment Station for publications on your particular problems. Good bulletins on Diseases of Bees, Care of Extracted Honey, Queen Bees, etc., have been published by the Bureau of Entomology, U. S. Department of Agriculture, Washington, D. C. 'The Massachusetts State Board of Agriculture has published bulletins on Brood Diseases, Essentials of Bee-keeping, and other phases of the subject.

The following bee journals, all of which are monthly, may be compared by securing, gratis, sample copies:

American Bee Journal, Hamilton, 11l., \$1.

The Domestic Bee-keeper, North Star, Mich., \$1. (Official organ of the National Bee-keepers' Association.) Paper and membership, $\$ 1$.

Canadian Horticulturist and Bee-keeper, Peterboro, Ontario, $\$ 1$.

Gleanings in Bee Culture, $A$. I. Root Co., Medina, Ohio, $\$ 1$.

Western Honey Bee, Los Angeles, Cal., $\$ 1$. 


Bee keeping in Rhode Island.

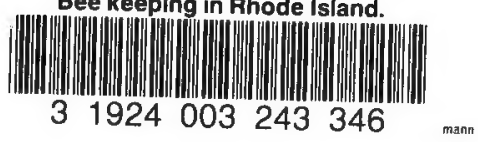


